Installation Restoration Research Program

Exploration of the Potential for Phytoremediation of Lead-Based-PaintContaminated Soil at Fort Lewis, WA

Elly P. H. Best, Kaaren N. Geter, and Steven L. Larson September 2004 


\section{Exploration of the Potential for Phytoremediation of Lead-Based-Paint-Contaminated Soil at Fort Lewis, WA}

Elly P. H. Best and Steven L. Larson

Environmental Laboratory

U.S. Army Engineer Research and Development Center

3909 Halls Ferry Road

Vicksburg, MS 39180-6199

Kaaren N. Geter

Analytical Services, Inc.

3532 Manor Drive, Suite \#3

Vicksburg, MS 39180

Final report

Approved for public release; distribution is unlimited 


\section{ABSTRACT:}

The current study was conducted to explore the potential for two phytoremediation strategies to remediate lead-based-paint- (LBP) contaminated soil from Fort Lewis, WA, i.e., phytoextraction and phytostabilization. The specific objectives were to (1) determine the potential for phytoextraction and phytostabilization of metals from $\mathrm{Pb}$-contaminated soil from Fort Lewis in herbaceous plants, (2) evaluate the effects of the vegetation on the leachability of the soil, and (3) evaluate the influence of differences in soil characteristics on the vegetation responses.

The tests were performed using Alopecurus pratensis (meadow foxtail) and Festuca rubra (red fescue), i.e., two metal-tolerant turf grass species, with current geographical distributions that include the State of Washington. The plants were incubated with field soil mixtures in a greenhouse on the U.S. ERDC-EL grounds in Vicksburg, MS.

Test results indicated that $A$. pratensis produced on average about twice as much plant biomass as F. rubra in 49 days, i.e., 546 versus $249 \mathrm{~g} \mathrm{DW} \mathrm{m}^{-2}$. Both species allocated most of their biomass below ground, and showed the tendency to accumulate $\mathrm{Pb}$ solely below ground without upward transport, and to accumulate $\mathrm{Zn}$ largely below ground with limited upward transport. The latter characteristic is typical for plant species used in phytostabilization strategies. A. pratensis was the better metal accumulator, which allocated a relatively higher proportion of its biomass in roots, but was also more sensitive to $\mathrm{Zn}$ than F. rubra. Presence of the vegetation increased the leachability of the soil considerably, but the leachable metal fractions were extremely low (0-0.3 percent) compared to the total soil metal levels. The metals contained in the plant mass represented maximally 2.2 percent of the total metals presumed to be present on site, with only a very small fraction contained in the above-ground, easily harvestable, biomass. Soil$\mathrm{Pb}$ was less bioavailable and accumulated to a lesser extent in the plant material than $\mathrm{Zn}$, probably because $\mathrm{Pb}$ was largely in the form of paint crystals. Increasing soil- $\mathrm{Pb}$ levels, concomitant with soil- $\mathrm{Zn}$ levels, significantly reduced the shoot and root biomass, increased the tissue- $\mathrm{Zn}$ concentrations in the shoots, and increased the tissue- $\mathrm{Pb}$ and $-\mathrm{Zn}$ concentrations in the roots. Increasing soil organic matter and moisture contents generally stimulated the production of shoot and root biomass.

It was concluded that phytostabilization appears to be a strategy that would considerably reduce ecological risk posed by LBP-contaminated soils at Fort Lewis. The vegetation would concentrate most of the mobile $\mathrm{Pb}$-fraction of the LBP in its root zone, and prevent metals from off-site release as parts of dust particles or dissolved within surface runoff. A. pratensis would be the most suitable species for use on soil contaminated by $\mathrm{Pb}$ alone, and F. rubra on soil contaminated by both $\mathrm{Pb}$ and $\mathrm{Zn}$. Regular mowing and mulching would be a viable management option, which would not spread $\mathrm{Pb}$ around and leave the vegetation intact. Potentially even lower bioavailability and solubility of the LBP-related $\mathrm{Pb}$ in the soil may be attained by removal of the upper $7.5 \mathrm{~cm}$ of the soil or amendment with phosphate rocks.

DISCLAIMER: The contents of this report are not to be used for advertising, publication, or promotional purposes. Citation of trade names does not constitute an official endorsement or approval of the use of such commercial products. All product names and trademarks cited are the property of their respective owners. The findings of this report are not to be construed as an official Department of the Army position unless so designated by other authorized documents. 


\section{Contents}

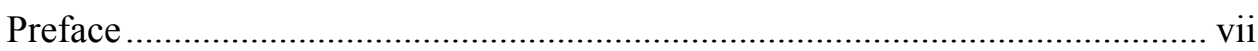

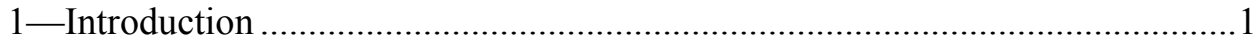

Lead-Based Paint ....................................................................................... 1

Phytoremediation of Metals and Considerations for Its Application to

Lead Contamination of Soil from Fort Lewis .........................................2

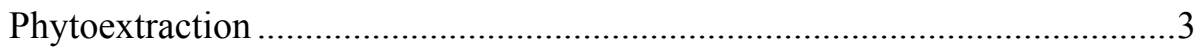

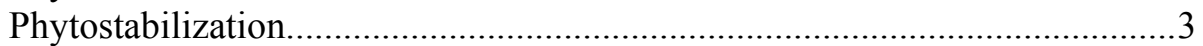

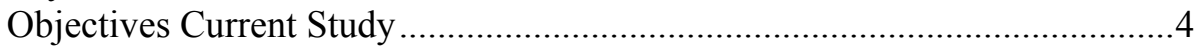

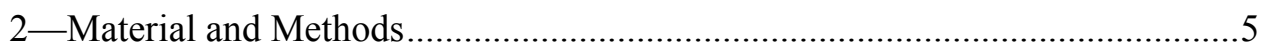

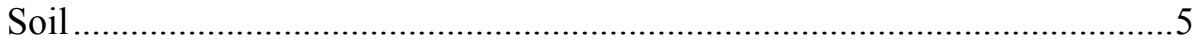

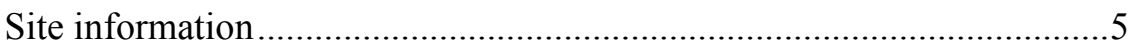

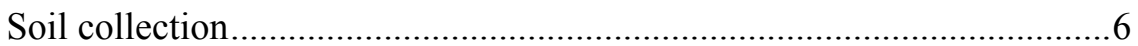

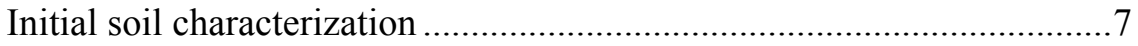

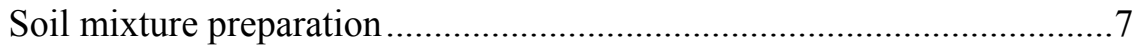

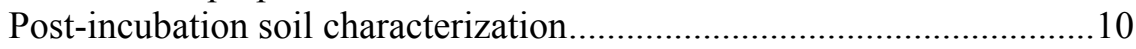

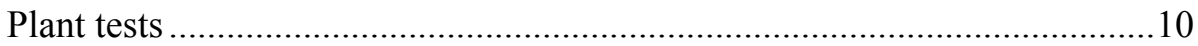

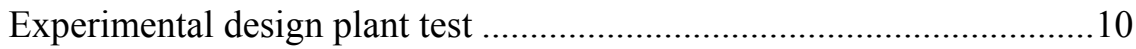

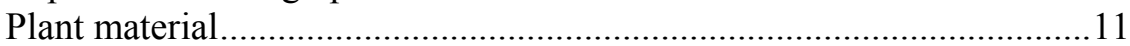

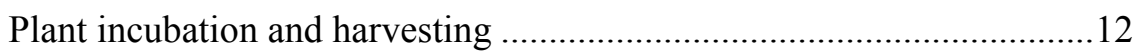

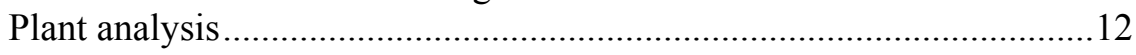

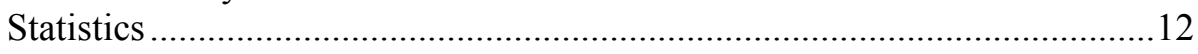

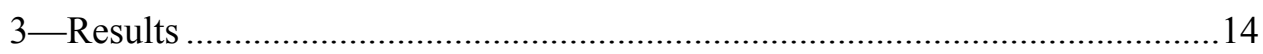

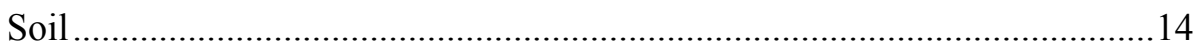

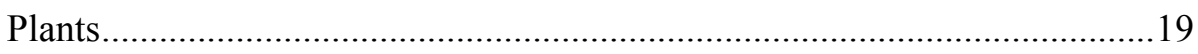

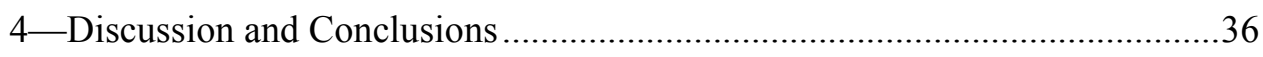

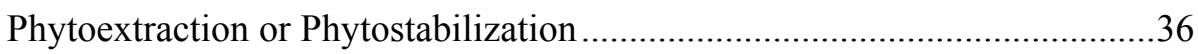

Effects of the Vegetation on the Leachability of the Soil .............................36

Effects of Soil Characteristics on the Vegetation Responses.........................36

Potential Importance of Phytoremediation Using the Tested Grass

Species for Remediation of Lead-Based Paint Contamination at

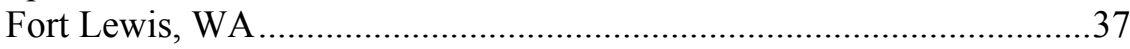

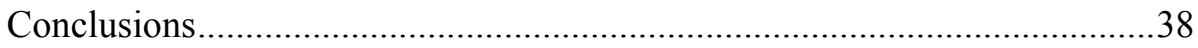

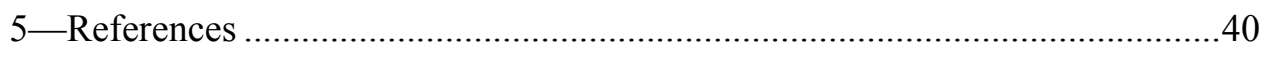

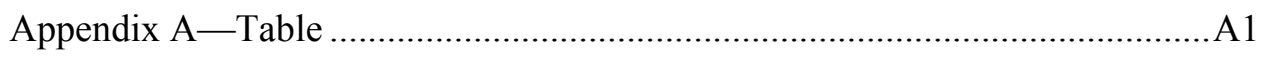




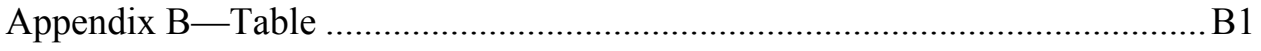

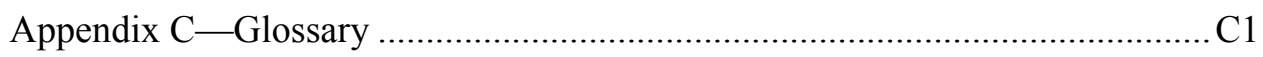

SF 298

\section{List of Figures}

Figure 1. Location of Fort Lewis, WA ….................................................5

Figure 2. Sites at Fort Lewis, WA, from which the source soils for the tests were excavated ........................................................

Figure 3. Shoot, root, and total plant mass produced by A. pratensis in 49 days in relation to soil lead concentration ......................................................................2 23

Figure 4. Shoot, root, and total plant mass produced by A. pratensis in 49 days in relation to soil zinc concentration....

Figure 5. Shoot, root, and total plant mass produced by F. rubra in 49 days in relation to soil lead concentration

Figure 6. Shoot, root, and total plant mass produced by F. rubra in 49 days in relation to soil zinc concentration

Figure 7. Tissue lead concentrations in shoot, root, and whole plant mass of $A$. pratensis in relation to soil lead concentration, accumulated in 49 days .

Figure 8. Tissue zinc concentrations in shoot, root, and whole plant mass of $A$. pratensis in relation to soil zinc concentration, accumulated in 49 days .

Figure 9. Tissue lead concentrations in shoot, root, and whole plant mass of F. rubra in relation to soil lead concentration, accumulated in 49 days

Figure 10. Tissue zinc concentrations in shoot, root, and whole plant mass of F. rubra in relation to soil zinc concentration, accumulated in 49 days. 


\section{List of Tables}

Table 1. Characteristics of Soil Samples Used to Create the Soil

Mixtures for the Tests ............................................................ 8

Table 2. Mixing Schedule Soil Mixtures; Numbers are in L.....................8

Table 3. Characteristics of the Soil Mixtures Prior to Incubation .............15

Table 4. Differences in Soil Mixture Parameters Prior to Incubation, as Tested for Statistical Significance Using ANOVA, Taking Pb Class, Organic Matter Class, and Their Interaction as Factors

Table 5. Leachable Metal Fractions and $\mathrm{pH}$ in Soil Mixtures After 49-d Incubation with $A$. pratensis and $F$. rubra

Table 6. Differences in Soil Mixture Parameters After 49-d Incubation with A. pratensis and F. rubra, as Tested for Statistical Significance Using ANOVA, Taking Species, $\mathrm{Pb}$ Class, Organic Matter Class, Moisture Class, and Their Interactions as Factors, and Block as Covariate

Table 7. Leachable Metal Quantities Prior to and After 49-d Incubation with $A$. pratensis and $F$. rubra 18

Table 8. Biomass of Whole Plants, Shoots, and Roots of A. pratensis and F. rubra After 49-d Incubation, Listed by Treatment for Each Plant Compartment.

Table 9. Differences in Plant Biomass Parameters After 49-d Incubation, as Tested for Statistical Significance Using ANOVA, Taking Species, Pb Class, Organic Matter Class, Moisture Class, and Their Interactions as Factors, and Block as Covariate.

Table 10. $\quad \mathrm{Pb}$ and $\mathrm{Zn}$ Concentrations in Whole Plants, Shoots, and Roots of A. pratensis and F. rubra After 49-d Incubation, Listed by Treatment for Each Plant Compartment.

Table 11. Results of Multiple Regression Analyses on Soil Characteristic Variables With Plant Responses of A. pratensis..... .32

Table 12. Results of Multiple Regression Analyses on Soil Characteristic Variables With Plant Responses of F. rubra 
Table 13. Plant Responses in Terms of Shoot and Root Biomass, and Their Associated Tissue-Metal Concentrations and Biota to Soil Accumulation Factors (BAF), Calculated Using the Multiple Regression Equations

Table 14. Commonly Cited Deficient, Normal, and Phytotoxic Metal Concentrations in Mature Plant Shoot Tissues

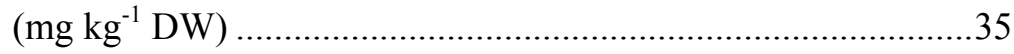

Table 15. Estimates of Lead and Zinc Quantities Present in the Upper 33-cm Soil Surface Layer in the MetalsContaminated Area of Fort Lewis, Their Leachable Fractions, and 49-day Accumulation in A. pratensis and F. rubra Vegetation. .38 


\section{Preface}

The work reported herein was conducted by the Environmental Laboratory (EL) of the U.S. Army Engineer Research and Development Center (ERDC), Vicksburg, MS. The research was conducted as part of the U.S. Army Fort Lewis, WA, "Identification of treatment technologies of lead-based-paint-contaminated soils" project, involving the U.S. Army ERDC-EL and U.S. Army Construction Engineering Research Laboratory (CERL) as lead agencies, with the U.S. Army ERDC-EL providing technical support. Additional financial support was provided by the Installation Restoration Research Program (IRRP) and the Environmental Quality Basic Research Program. For the latter program, Dr. M. John Cullinane, EL, was the Program Manager, and Dr. Clem Meyer was the IRRP Coordinator at the Directorate of Research and Development, Headquarters, U.S. Army Corps of Engineers. This project encompassed two small-scale treatability studies in 2001 to explore, respectively, the potential for cleanup using phytoremediation, and to explore the potential for cleanup using electrokinetics. Based on the thus-generated information, a field-scale treatability study will be designed and executed in 2002. The current report pertains to the exploratory phytoremediation study.

The principal investigator for this work was Dr. Elly P.H. Best, Environmental Risk Assessment Branch (ERAB), Environmental Processes and Engineering Division (EPED), EL. Ms. Kaaren N. Geter, Analytical Services Incorporated, Vicksburg, MS, provided technical support. The report was authored by Dr. Elly P.H. Best and Ms. Kaaren N. Geter. Dr. Steven Larson, Environmental Engineering Branch (EEB), EPED, EL, provided funding via the abovementioned programs, generated information on the physical status of lead in the Fort Lewis soil, and provided valuable comments on the report.

Special thanks go to the following Corps of Engineers personnel who gave generously of their time and expertise to review the first draft: Dr. Judy Pennington for her review of plant tests, and Ms. Cindy Teeter for her review of engineered application possibilities. Mr. Richard W. Wilson, Environmental and Natural Resources Division, Fort Lewis Public Works, WA, is also gratefully acknowledged for his comments on a later draft.

The study was conducted under the direct supervision of Dr. Richard E. Price, Chief, EPED, and under the general supervision of Dr. Edwin A. Theriot, Director, EL.

At the time of preparation of this report, Dr. James R. Houston was Director of ERDC, and COL James R. Rowan, EN, was Commander and Executive Director. 


\section{Introduction}

\section{Lead-Based Paint}

Lead is strongly resistant to corrosion in various aggressive environments, such as strongly acidic ones. In air, for instance, a close-fitting and adherent film of lead carbonate is formed by rapid reaction, first between metallic lead and oxygen to form lead oxide, followed by a second reaction between the lead oxide film and carbon dioxide from the air, to form a protective film of lead carbonate. Further contact with the metallic lead underneath is then prevented and corrosion ceases.

Until 1978 lead was widely used in paints. White lead, basic lead carbonate, was used in decorative paints and to promote good weathering characteristics. Red lead is the traditional pigment for rust-inhibiting priming paints applied directly to iron and steel. Calcium-plumbate-based paints are particularly effective on galvanized steel, precluding the need for etch primers. Lead chromate (yellow) and lead molybdate (red-orange) are still used in plastics and to a lesser extent in paints. Lead chromate is used extensively as the yellow pigment in road markings. Despite the fact that lead-based paint provided long-lasting protection of buildings and structures, in the course of time some weathering, peeling, and particularly leaching occurred under wet, acid conditions. The latter processes could release considerable quantities of lead from the painted buildings and structures, and introduce the lead in its various complex forms into the environment. Chemical species of lead in soil are usually bioavailable to a very low extent if the soil is ingested by children, livestock, or wildlife (Chaney and Ryan 1994). Concern for potentially toxic effects in humans colonizing or inhabiting the contaminated areas spurred the U.S. Environmental Protection Agency (USEPA) to issue a directive in 1978 that all paint manufactured in the United States be lead-free. However, even today lead from lead-based paint is still released into the environment by weathering, peeling, and leaching from standing and demolished buildings and structures. 


\section{Phytoremediation of Metals and Considerations for Its Application to Lead Contamination of Soil from Fort Lewis}

Remediation of the environment can be carried out by several strategies that either remove contaminants or stabilize them within the soil. Procedures can include acid leaching of contaminants, excavation and storage of the soil itself, physical separation of the pollutants, and electrochemical processes (Acar and Alshawabkwe 1993). Phytoremediation is defined as the use of green plants to remove pollutants from the environment or to render them harmless (Salt et al. 1998). Phytoremediation may involve three different activities:

(1) phytoextraction, i.e., uptake, compartmentation, and possibly degradation of the contaminant; (2) phytostabilization, i.e., the on-site containment of the contaminant without uptake within plant tissues, and (3) plant-assisted bioremediation, i.e., degradation by plant-associated microorganisms. As with engineering technologies, plant-based remediation techniques can be employed to accomplish either contaminant removal or containment/isolation. Phytoremediation has developed into a promising, cost-effective, and environmentally friendly technology that can be applied to both inorganic and organic pollutants, present in solid substrates (e.g., soil), liquids (e.g., water), and air. The overriding advantage of phytoremediation is that the procedure is carried out in situ and can be far less expensive than physical methods such as the removal of soil. Classical remediation methods can cost around $\$ 100,000-\$ 1,000,000$ per ha for in-situ remediation of water-soluble pollutants. Cunningham et al. (1995a) give an estimate of $\$ 200-\$ 10,000$ per ha for phytoremediation techniques.

A general limitation of all biological systems in site cleanup is that for the plant or plant-associated microflora to interact and remediate the contaminant, the contaminant must be biologically available. Contaminants sequestered into clay lattices, absorbed by humic fractions, and occluded by oxide coatings are not accessible to most biological processes and are extremely stable. Although they may be detected by exhaustive extraction techniques, the hazard that these materials pose to the environment or human health is unknown and under debate. Bioavailability relative to both inherent hazard and the development of biological remediation technologies is currently an active research topic in remediation and the subject of task forces focused on the determination of "environmentally acceptable endpoints" (Cunningham et al. 1995b). Despite the increasing use of plants in the remediation of water and air, the use of plant-based systems to remediate contaminated soil is still in an early stage. Phytoextraction and plantassisted bioremediation of soil are both technically more difficult and they are, therefore, still in the research phase, but phytostabilization is a technology that is moving rapidly from the research into the development phase.

Most inorganic contaminants have multiple chemical and physical forms in the soil environment. Not all forms are equally hazardous, nor are all forms equally amenable to uptake by plants. Cunningham et al. (1995b) used a sequential chemical extraction procedure of $\mathrm{Pb}$ involving exposure of a contaminated soil sample to a series of solutions of increasing chemical harshness, with a complete nitric-perchloric acid sample digestion as the last step. They found that their 
Toxicity Characteristic Leaching Procedure (TCLP) could serve (1) as a measure of relative hazard posed by $\mathrm{Pb}$ in the matrix; (2) as a predictor of the success of phytostabilization relative to phytoextraction; and (3) as a first cut to suggest the applicability of engineering technologies that might be applied at the site.

\section{Phytoextraction}

For phytoextraction to be an economically viable technology, the contaminant must be available to and taken up by the plant roots. Translocation of the contaminant from roots to shoots must occur to ease the harvesting and minimize worker exposure during harvesting. After harvesting, a biomass-processing step may occur to recover the metal. Plants capable of accumulating more than 100 times larger concentrations of metals than non-accumulating plants have been termed hyperaccumulators (Brooks et al. 1977). Natural hyperaccumulators have been identified for several metals, i.e., cadmium, cobalt, copper, manganese, nickel, selenium, thallium, and zinc, but not for lead (Leblanc et al. 1997). However, lead accumulation in plants may be enhanced by soil application of chelates (Blaylock et al. 1997) and by genetic engineering of plants (Cunningham and Ow 1996). In phytomining, economic recovery of valuable metals is the objective. Phytomining is defined as the use of plants to harvest its metal content for economic return (Brooks 1997). Robinson et al. (1997) have calculated the required biomass for a hyperaccumulator with a metal content of 1 percent dry weight that would return $\$ 500 \mathrm{ha}^{-1}$ at recent world prices. The biomasses range from 0.0037 tonnes $\mathrm{ha}^{-1}$ for gold to 61.2 tonnes $\mathrm{ha}^{-1}$ for lead. Assuming that the upper limit for any annual crop is 30 tonnes $\mathrm{ha}^{-1}$ (equal to that of Zea mays, corn), only cobalt, nickel, tin, cadmium, manganese, and the noble metals would be amenable to this procedure.

\section{Phytostabilization}

Under a phytostabilizing strategy, the mobility of inorganic contaminants is reduced by the addition of soil amendments that reduce contaminant solubility. This can be accomplished by soil amendment with alkalinizing agents, such as calcium phosphate, mineral oxides, and organic matter. Phytostabilization, as a relatively new concept, borrows heavily from previous research on reclamation and revegetation of metal mine tailings and waste piles in England using metaltolerant plants (Bradshaw and Chadwick 1980). One of the benefits of these plants is that most of the metal absorbed remains in the roots, and, consequently, grazing can be used as a management strategy of these areas. It has to be noted, though, that animal grazing on these restored mine sites generally is limited to short time periods, and animals are rotated to uncontaminated land for much of their feeding requirements. A phytostabilization approach appears to hold a strong promise for lead. The bioavailability and solubility of lead are greatly decreased when lead is present in the form of a lead phosphate mineral, chloropyromorphite. However, the latter mineral is formed slowly because the reactants have low solubilities also (Ma et al. 1995; Cotter-Howells and Caporn 1996). Inactivating soil lead by use of soil amendments and revegetation to prevent 
erosion is increasingly regarded as a promising soil lead remediation technology (Chaney and Ryan 1994; Berti and Cunningham 1997).

In phytoremediation, recovery of metals for their commercial value is typically not the objective. However, even if the metals recovered within the plant material are not of economic importance, it would still be feasible to use plants as effective vectors to (1) extract and concentrate metals in shoots, which can be regularly harvested and exported from the site, thereby rendering excavation of the contaminated soil unnecessary; or (2) extract and concentrate metals in plant mass, thus preventing metals from being released from the site as parts of dust particles or dissolved within runoff or downward seepage, thereby rendering other remediation measures superfluous. The question remains, however, how large the actual metal quantities accumulated by metal-tolerant plants at specific metal-contaminated sites are, and whether these quantities are relevant compared to the amounts of total metals and their mobile fractions contained in the soil.

\section{Objectives Current Study}

The current study explores the potential for two phytoremediation strategies to remediate lead-based-paint-contaminated soil from Fort Lewis, WA, i.e., phytoextraction and phytostabilization. The specific objectives were to (1) determine the potential for phytoextraction and phytostabilization of metals from $\mathrm{Pb}$ contaminated soil from Fort Lewis in herbaceous plants, (2) evaluate the effects of the vegetation on the leachability of the soil, and (3) evaluate the influence of differences in soil characteristics on the vegetation responses. 


\section{Material and Methods}

\section{Soil}

\section{Site information}

Fort Lewis, WA, is located between Tacoma and Olympia $\left(47^{\circ} 30^{\prime} \mathrm{N}\right.$, $122^{\circ} 40^{\prime} \mathrm{W}$; Figure 1). The original military base, Camp Lewis, WA, dates back to 1917 when it housed 50,000 American troops. It was a large training site, and contained 1,757 buildings and 422 other structures, mostly wooden or temporary. In 1927 the construction of permanent brick structures on the base began and the camp was officially designated a permanent military base and renamed Fort Lewis. During the second World War wooden structures were added to the base, many of which remain to date.

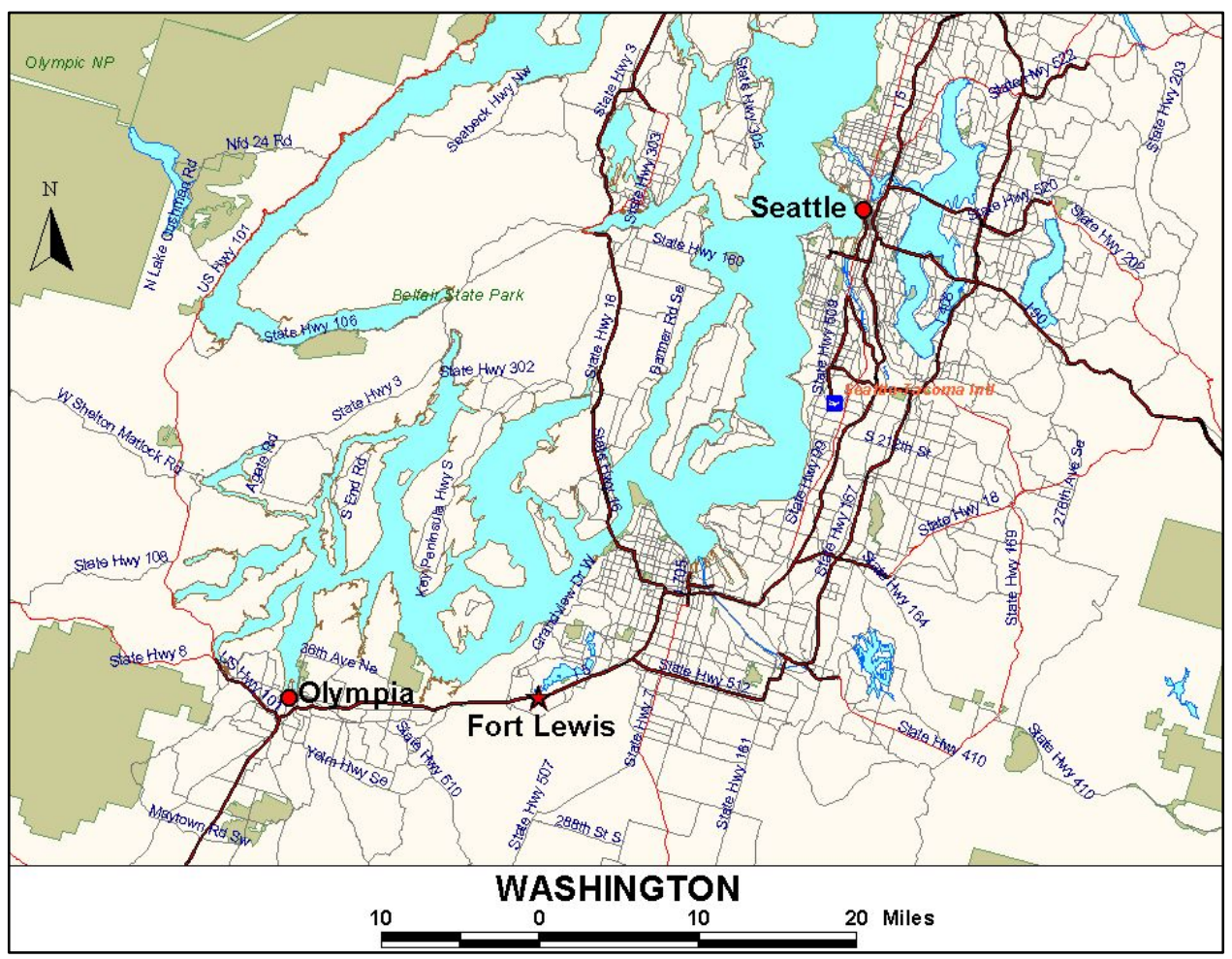

Figure 1. Location of Fort Lewis, WA (marked by a star) 
In an effort to update the housing and other structures on base, Fort Lewis is decommissioning and demolishing wooden structures built before the second World War. To evaluate the environmental consequences of the lead-based-paint contamination of the soil surrounding the buildings before and after demolition, Fort Lewis requested a survey to characterize the spatial distribution and extent of lead contamination at designated structures. Results of this site characterization, carried out in September 2000, indicated in the lead-based-paint-contaminated area between $\mathrm{C}$ Street and $\mathrm{D}$ Street moderate $\mathrm{Pb}$ levels in the range of 310$395 \mathrm{mg} \mathrm{kg}^{-1}$ dry weight (DW) in the upper $7.5 \mathrm{~cm}$ (3 inches) of the soil adjacent to several buildings, high levels of $3,360 \mathrm{mg} \mathrm{kg}^{-1} \mathrm{DW}$ close to the chapel, and site-background levels in the order of $70 \mathrm{mg} \mathrm{kg}^{-1} \mathrm{DW}$. For comparison, $\mathrm{Pb}$ levels at an active firing range, number 10 , were $38,872 \mathrm{mg} \mathrm{kg}^{-1} \mathrm{DW}$ (Anonymous 2001). As a follow-up, Fort Lewis requested bench-scale studies to explore the potential for site cleanup of lead using innovative technologies, including phytoremediation and electrokinetics, to form a basis for the implementation of subsequent site cleanup and/or management. The regulatory guideline for the cleanup level of lead in residential areas, including Fort Lewis, is $250 \mathrm{mg}$ $\mathrm{kg}^{-1}$ soil-DW for situations where contamination by one to two metals is present (Table 1; State of Washington Model Toxics Control Act regulation; MTCA 2002).

The soil at Fort Lewis is composed primarily of a well-drained glacial till of low moisture content and littered with small rocks. The former housing area between C Street and D Street is flat, and occupied by several buildings surrounded by grassy lawns and a mixture of pine and deciduous trees. Extensive moss carpets on the ground and on the roofs indicate acid precipitation.

The fact that lead-based paint is most likely the source of the $\mathrm{Pb}$ contamination around these buildings has been confirmed. X-ray diffraction patterns indicated that main components of the lead contamination were Rutile, $\mathrm{TiO}_{2}$, and hydrocerussite $\left(\mathrm{Pb}_{3}\left(\mathrm{CO}_{3}\right)_{2}(\mathrm{OH})_{2}\right)$. These crystalline paint components were present in all soil samples with high $\mathrm{Pb}$ concentrations, and relatively more crystals were visible under the scanning microscope at high $\mathrm{Pb}$ than at low $\mathrm{Pb}$ concentrations.

\section{Soil collection}

Two soil samples were collected from Fort Lewis, WA, to serve as sources for the preparation of a series of soil mixtures ranging from phytotoxic to background $\mathrm{Pb}$-levels. Selection of the sites for excavation was based on the site characterization carried out earlier (Anonymous 2001). Highly Pb-contaminated soil was sampled from a site adjacent to the chapel (Building A; A0102, Flag 36; Figure 2), and background soil from a wooded site $20 \mathrm{~m}$ north of the latter site. The soil was excavated from the soil surface to a depth of $33 \mathrm{~cm}$. At the highly $\mathrm{Pb}$-contaminated site, white paint chips were visible largely in the upper $7.5 \mathrm{~cm}$.

The material was transported to ERDC-EL in Vicksburg, MS, in drums. Upon arrival the material was dried to a moisture content of approximately 40 percent to allow persistence of the innate microbial community. The soil was 
homogenized, sieved over a $0.6 \mathrm{~cm}$ sieve, and stored in a cold room $\left(5^{\circ} \mathrm{C}\right)$ until use.

\section{Initial soil characterization}

Initially, the collected soils were surface-scanned for metal contamination using X-ray fluorescence spectrometry (XRF, Niton XL-722-XRF analyzer, with a $\mathrm{Pb}$-detection limit of $18.4 \mathrm{mg} \mathrm{kg}^{-1} \mathrm{DW}$ ). Subsequently, total metal concentrations in the soils were determined in acid digests and analyzed using ICP-ES (see below). The soil collected near Building A contained high levels of lead and zinc and levels of chromium, vanadium, and copper exceeding the Chemical Stressor Concentration Level (CSCL), a level at which growth-inhibiting effects in plants are to be expected (USEPA 1999, Table 1). Contamination by PCBs and PAHs proved to be absent.

\section{Soil mixture preparation}

The following three soil samples were used to create a series of soil mixtures with $\mathrm{Pb}$ concentration increasing up to $346 \mathrm{mg} \mathrm{kg}^{-1} \mathrm{DW}$ and two organic matter levels: (1) soil from the Building A site, (2) soil from the background site, and (3) Baccto R Lite potting soil (Tables 1 and 2). Baccto R Lite potting soil (8590 percent organic Sphagnum) was purchased from the Michigan Peat Company, Houston, TX. Portions of the soil samples were measured volumetrically (Table 2) and mixed using a V-mixer (Patterson-Kelly Company, East Stroudsburg, PA).

All soil mixtures were analyzed for chemical and physical characteristics, in triplicate. The total concentrations of $\mathrm{Pb}, \mathrm{Zn}, \mathrm{Cr}, \mathrm{Ni}, \mathrm{Hg}$, and $\mathrm{Fe}$ were determined. Soil fertility was evaluated by determining the nitrate-N, infinite sink-P, and total-K concentrations. Other parameters assessed were $\mathrm{pH}$, organic matter content, and bulk density.

Chemical analyses. The total metal concentrations were determined, including $\mathrm{Pb}, \mathrm{Zn}, \mathrm{Fe}, \mathrm{Cr}, \mathrm{Ni}$, and $\mathrm{Hg}$. For the analysis of all metals except $\mathrm{Hg}$, $0.5 \mathrm{~g}$ dry soil material was digested using a 25 percent dilution of concentrated nitric acid in a microwave oven (OI Analytical Model 7195; OI Analytical Corp., College Station, TX). Metals were analyzed in the diluted extracts using Inductively Coupled Plasma Analysis Emission Spectrometry (ICP-ES; Perkin Elmer Optima 3300 DV ICP, Perkin Elmer Instruments, Shelton, CT; USEPA Method 3050, USEPA 1996). Hg was determined in fresh soil samples using the cold vapor method (USEPA Method 7471, USEPA 1994). 


\begin{tabular}{|c|c|c|c|c|c|}
\hline \multicolumn{6}{|c|}{$\begin{array}{l}\text { Table } 1 \\
\text { Characteristics of Soil Samples Used to Create the Soil Mixtures for } \\
\text { the Tests }\end{array}$} \\
\hline \multirow[b]{2}{*}{ Characteristic } & \multicolumn{3}{|c|}{ Soil Sample } & \multirow[b]{2}{*}{$\begin{array}{l}\text { USEPA } \\
\text { Guideline }\end{array}$} & \multirow{2}{*}{$\begin{array}{l}\text { Regulatory } \\
\text { Limit } \\
\left(\mathbf{m g ~ k g} \mathbf{~}^{-1}\right. \\
\text { DW) }\end{array}$} \\
\hline & \begin{tabular}{|l} 
Building A \\
Fort Lewis \\
\end{tabular} & $\begin{array}{l}\text { Site- } \\
\text { Background } \\
\text { Fort Lewis } \\
\end{array}$ & Baccto-Lite & & \\
\hline \multicolumn{6}{|c|}{ Total Metals $\left(\mathrm{mg} \mathrm{kg}^{-1} \mathrm{DW}\right)$} \\
\hline Lead & $3360 \pm 56.57$ & $71.4 \pm 1.56$ & 6.89 & 50 & 250 \\
\hline Zinc & $1330 \pm 56.57$ & $99.25 \pm 26.52$ & 18.21 & 50 & none \\
\hline Chromium & $25.0 \pm 0.0$ & $24.5 \pm 0.0$ & $<0.06$ & 1 (IV) & $2 \times 10^{3}$ \\
\hline Nickel & $25.7 \pm 0.28$ & $29.2 \pm 4.95$ & 5.00 & 30 & \\
\hline Cadmium & $<3.60$ & $<3.0$ & 1.24 & 4 & 2 \\
\hline Vanadium & $49.0 \pm 1.13$ & $44.0 \pm 2.62$ & 5.70 & 2 & \\
\hline Mercury & $4.25 \pm 0.71$ & $0.26 \pm 0.15$ & 0.08 & $0.1\left(\mathrm{Hg}^{2+}\right)$ & 2 \\
\hline Copper & $55.4 \pm 2.19$ & $27.5 \pm 0.57$ & 4.1 & & none \\
\hline Arsenic & $29.1 \pm 0.99$ & $21.6 \pm 0.42$ & 5.0 & & 20 \\
\hline Aluminium & $24950 \pm 494.97$ & $21850 \pm 70.71$ & 3010 & & \\
\hline Iron & $19550 \pm 212.13$ & $17550 \pm 212.13$ & 3010 & & \\
\hline Manganese & $502.5 \pm 13.44$ & $495.0 \pm 4.24$ & 39.4 & & \\
\hline \multicolumn{6}{|c|}{ Nutrients $\left(\mathrm{mg} \mathrm{kg}^{-1} \mathrm{DW}\right)$} \\
\hline Nitrate-N & $13.99 \pm 6.06$ & $8.08 \pm 1.27$ & 122.6 & & \\
\hline Infinite-sink P & $1.81 \pm 0.27$ & $1.72 \pm 0.67$ & 14.03 & & \\
\hline Total-K & $36.38 \pm 2.82$ & $26.24 \pm 0.74$ & ND & & \\
\hline \multicolumn{6}{|c|}{ Other } \\
\hline $\mathrm{pH}_{\text {water }}$ & $5.37 \pm 0.01$ & $5.09 \pm 0.01$ & $5.13 \pm 0.04$ & & \\
\hline Organic Matter (\% DW) & $19.72 \pm 0.23$ & $14.11 \pm 0.56$ & $74.38 \pm 2.06$ & & \\
\hline Dry Weight (\% FW) & $86.83 \pm 0.13$ & $91.74 \pm 0.34$ & $39.80 \pm 1.13$ & & \\
\hline Bulk Density (g DW/mL) & $1.32 \pm 0.41$ & $1.45 \pm 0.13$ & $1.27 \pm 0.23$ & & \\
\hline \multicolumn{6}{|c|}{$\begin{array}{l}\text { Note: Critical Stressor Concentration Levels (CSCL, USEPA 1999) are given for comparison, and } \\
\text { regulatory limits for the State of Washington (cf. the State of Washington Model Toxics Control Act, } \\
\text { MCTA; } h \text { ttp://www.ecy.wa.gov/biblio/wac173340.htm/) are given for reference. } \\
\text { Abbreviations: ND, not determined } \\
\text { Mean values and standard deviations }(\mathrm{N}=2)\end{array}$} \\
\hline
\end{tabular}

\begin{tabular}{|c|c|c|c|c|c|c|c|c|}
\hline \multicolumn{9}{|c|}{$\begin{array}{l}\text { Table } 2 \\
\text { Mixing Schedule Soil Mixtures; Numbers are in } L\end{array}$} \\
\hline \multirow[b]{2}{*}{ Soil sample } & \multicolumn{8}{|c|}{ Soil mixture } \\
\hline & $\begin{array}{l}14 \mathrm{OM}^{\mathrm{a}} \\
{\mathrm{MB}-\mathrm{Pb}^{\mathrm{b}}} \\
\mathrm{Mix} 1\end{array}$ & $\begin{array}{l}14 \mathrm{OM} \\
233 \mathrm{~Pb} \\
\text { Mix } 2\end{array}$ & $\begin{array}{l}14 \mathrm{OM} \\
256 \mathrm{~Pb} \\
\text { Mix } 3\end{array}$ & $\begin{array}{l}14 \mathrm{OM} \\
331 \mathrm{~Pb} \\
\mathrm{Mix} 4\end{array}$ & $\begin{array}{l}20 \text { OM } \\
\text { MB-Pb } \\
\text { Mix } 5\end{array}$ & $\begin{array}{l}20 \mathrm{OM} \\
233 \mathrm{~Pb} \\
\text { Mix } 6\end{array}$ & $\begin{array}{l}20 \mathrm{OM} \\
256 \mathrm{~Pb} \\
\text { Mix } 7\end{array}$ & \begin{tabular}{|l|}
$20 \mathrm{OM}$ \\
$331 \mathrm{~Pb}$ \\
Mix 8 \\
\end{tabular} \\
\hline Fort Lewis Building A (high-Pb) & 0 & 2.90 & 5.76 & 11.52 & 0 & 2.90 & 5.76 & 11.52 \\
\hline Fort Lewis background & 13.30 & 14.50 & 11.24 & 6.78 & 11.00 & 8.60 & 5.00 & 0 \\
\hline Baccto-Lite soil (high OM) & 5.70 & 1.60 & 2.00 & 0.70 & 8.00 & 7.50 & 8.24 & 7.50 \\
\hline \multicolumn{9}{|c|}{$\begin{array}{l}\text { Abbreviations: MB, mixture background. } \\
\text { a Organic matter (OM) classes in \%DW } \\
{ }^{\mathrm{b}} \mathrm{Pb} \text { classes in } \mathrm{mg} \mathrm{kg}^{-1} \mathrm{DW}\end{array}$} \\
\hline
\end{tabular}




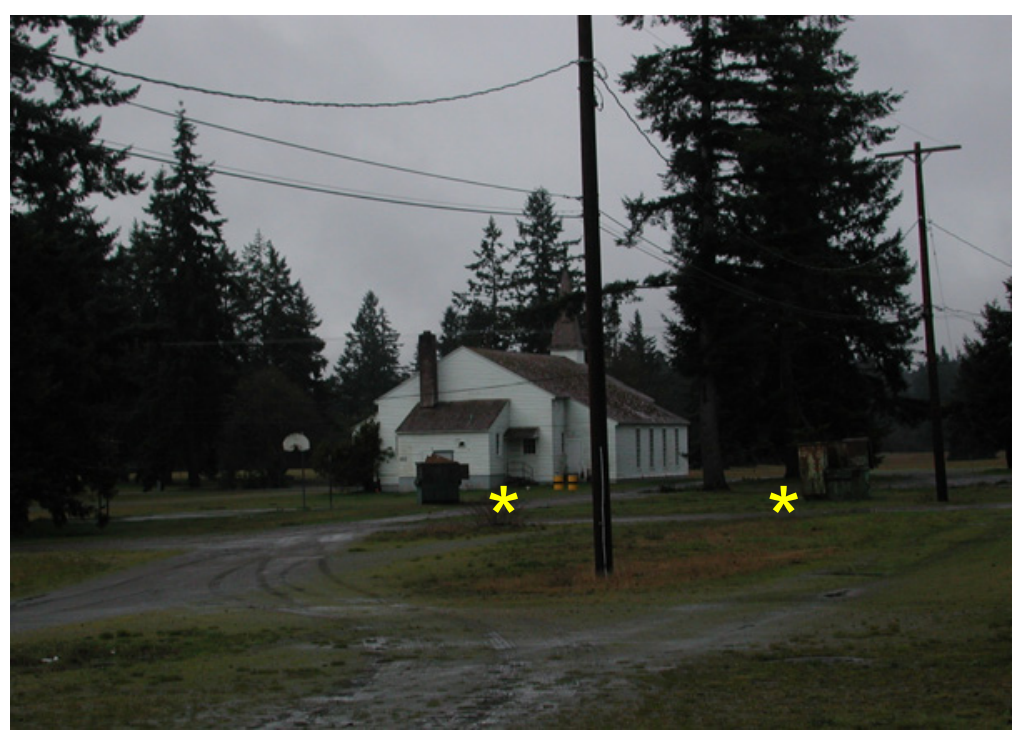

Figure 2a. Sites at Fort Lewis, WA, from which the source soils for the tests were excavated. The high-Pb soil was collected next to the chapel (Building $A$ ) and the background soil from a wooded site $20 \mathrm{~m}$ removed from the chapel (sites marked by asterisks)

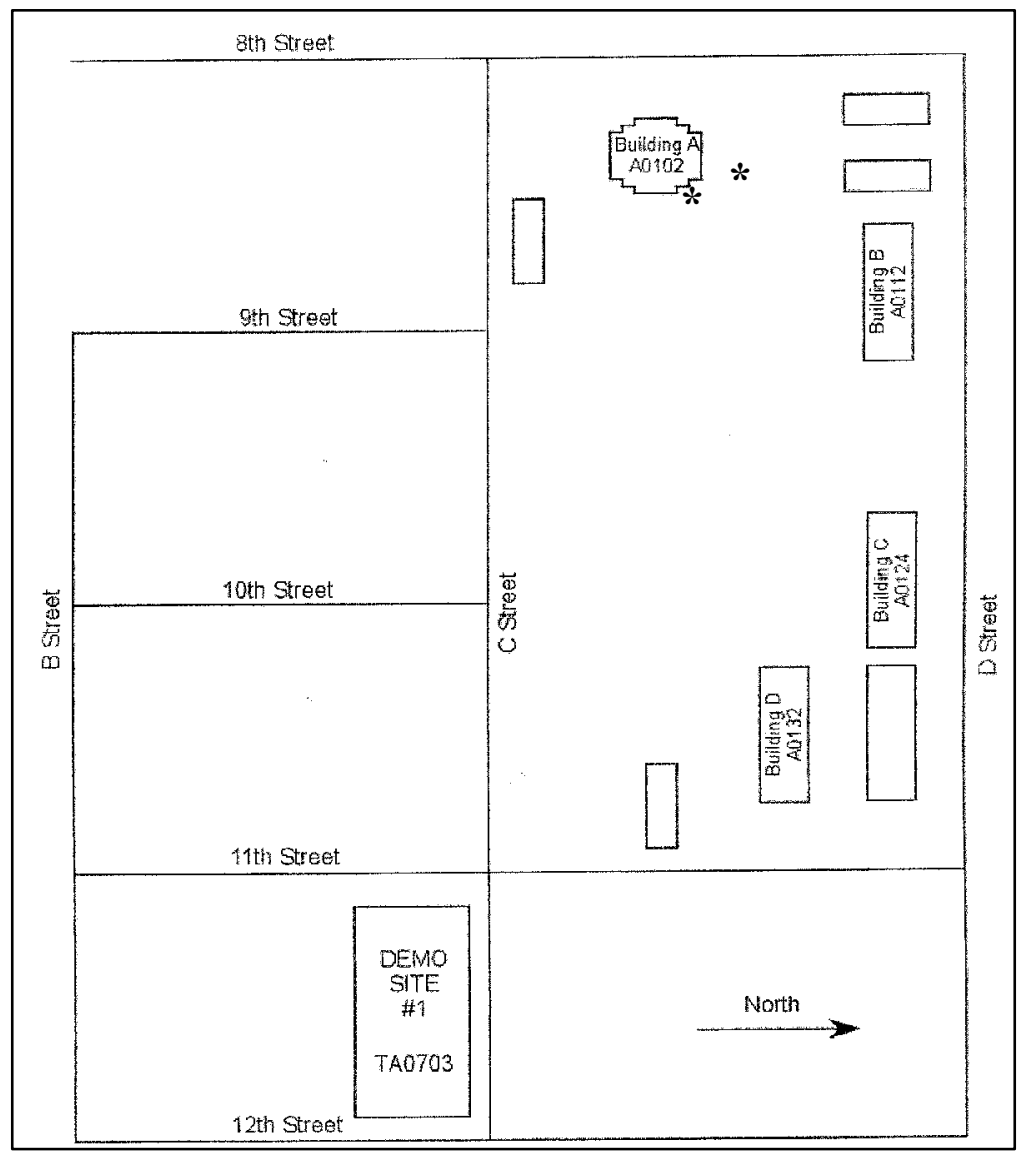

Figure $2 b$. Sites at Fort Lewis, WA, from which the source soils for the tests were excavated. Sites are marked by asterisks 
The leachable metal concentrations were determined using a batch leach (BL) procedure modified after Brannon et al. (1994). For this, an amount of fresh soil equivalent to $45 \mathrm{~g}$ dry weight was weighed, transferred into 250 -mL polycarbonate centrifuge tubes, and wetted with reverse osmosis (RO) water up to a final water:soil ratio of 4:1. This first step was not performed in an anaerobic environment as is done for sediments, because the upper soil layers at Fort Lewis are well drained, making anaerobic conditions unlikely to occur. Subsequently, the tubes were placed in a rotary tumbler for $24 \mathrm{~h}$, centrifuged for $30 \mathrm{~min}$ at $9,000 \mathrm{~g}$. The contents were filtered through a $0.45-\mu \mathrm{m}$ membrane filter, the leachates collected and acidified with $1 \mathrm{~mL}$ concentrated Ultrex $\mathrm{HCl}$ per L. The samples were stored in the dark prior to analysis of metals by ICP-ES. The leachates were analyzed for $\mathrm{Pb}, \mathrm{Zn}, \mathrm{Fe}, \mathrm{Cr}$, and $\mathrm{Ni}$.

The following macro-nutrients were determined. Nitrate-N was measured after conversion to ammonia, as ammonia using a Hach spectrophotometer DR/2000 (Hach 1992). Plant-available $P$ was determined as infinite-sink phosphorus $\left(\mathrm{P}_{\mathrm{i}}\right)$ concentration according to Van der Zee et al. (1987). The $\mathrm{P}_{\mathrm{i}}$ determination measures both, $\mathrm{P}$ fractions relatively rapidly adsorbed to $\mathrm{Fe}$ and $\mathrm{Al}$, and $\mathrm{P}$ fractions relatively slowly precipitating. Total $\mathrm{K}$ was determined by extraction in a hydrochloric acid/oxalic acid mixture, and measuring the cesium chloride complex spectrophotometrically according to Houba et al. 1995.

Physical analyses. The moisture content was determined by drying at $105{ }^{\circ} \mathrm{C}$ in a forced-air oven until constant weight. Concentrations of organic matter were determined by loss on ignition at $550{ }^{\circ} \mathrm{C}$, and bulk density volumetrically (Allen et al. 1974). $\mathrm{pH}_{\mathrm{KCl}}$ was measured with a $\mathrm{pH}$ meter (Beckman Model PHI40, Fullerton, $\mathrm{CA})$ in a $1 \mathrm{M} \mathrm{KCl}$ solution in a fresh soil-to-liquid ratio of 1:2.5 (w/v). $\mathrm{pH}_{\mathrm{KCl}}$ was converted to $\mathrm{pH}_{\text {water }}$ using a regression equation of $\mathrm{pH}_{\text {water }}=0.677 \mathrm{x}$ $\mathrm{pH}_{\mathrm{KCl}}+2.35$. (ISO 10390, Best and Jacobs 2001).

\section{Post-incubation soil characterization}

After incubation, all soil units were analyzed for the leachable fractions of metals and $\mathrm{pH}$. The total metal concentrations were not determined since the changes in their concentrations were expected to be negligible.

\section{Plant Tests}

\section{Experimental design plant test}

The plant test used the following treatments.

- Pb concentration: Four levels, i.e., mixture-background (50), 233, 256, and $331 \mathrm{mg} \mathrm{Pb} \mathrm{kg}^{-1}$ soil-DW. A level of $310-395 \mathrm{mg} \mathrm{Pb} \mathrm{kg}^{-1}$ soil DW was considered as representative for the upper $0.33 \mathrm{~m}$ of the soil adjacent to several buildings in the lead-contaminated area between C Street and D Street at Fort Lewis, according to the site characterization report (Anonymous 2001). Several levels between 50 and $331 \mathrm{mg} \mathrm{Pb} \mathrm{kg}^{-1} \mathrm{DW}$ were tested also, since a level higher 
than $50 \mathrm{mg} \mathrm{Pb} \mathrm{kg}^{-1} \mathrm{DW}$ is considered as stressful for plants (USEPA 1999), but consequences for biomass formation are largely unknown.

- Organic matter concentration: Two levels, i.e., 14 and 20 percent DW. Target organic matter levels were originally selected to represent (1) contaminated sites around other buildings where the largely mineral soil had been enriched by the inhabitants with organic-matter-rich potting soil in attempts to grow garden plants and (2) the site near Building A. Important roles of organic matter in soil are to serve as adsorptive substrate (e.g., for metals) and as a source of macronutrients (e.g., nitrogen and phosphorus). Unfortunately, the target levels were not unequivocally attained by our mixing procedure.

- Moisture level: Two levels, i.e., close to $1 / 3$ field capacity (10 percent) and close to field capacity ( 39 percent, field capacity being 40 percent). Two plant species were included in the test.

A multifactorial, randomized block design with four blocks was used, with four replicates per treatment. Each block contained one replicate of each treatment. The study included a total of 128 units (four $\mathrm{Pb}$ concentrations $\times$ two $\mathrm{OM}$ levels $\times$ two moisture levels $\times$ four replicates $\times$ two plant species).

\section{Plant material}

Choice of plant species for current study. Selection of the plant material was based on the following criteria: (1) herbaceous growth form; (2) not invasive in the State of Washington; (3) wide geographical distribution, including the State of Washington; (4) propagules easy to obtain (or purchase) and grow; (5) listed as tolerant towards lead, and possibly other metals that often accompany lead; (6) listed as accumulating lead either preferentially in shoots and/or roots (Ebbs et al. 1997). Two monocotyledonous grass species were used in the tests, meeting criteria 1-6, i.e., Alopecurus pratensis (meadow foxtail) and Festuca rubra (red fescue). A. pratensis accumulates its biomass largely in roots, and F. rubra largely in shoots. F. rubra is widely distributed in Northern Europe and North America. A. pratensis is a native of Eurasia and has been naturalized in North America (Gleason and Cronquist 1991).

These species were selected because no grass species native to the State of Washington were found, known to meet all following requirements: (1) produce a reasonably high biomass, (2) metal-tolerant, (3) high metal accumulation potential, (4) tolerate regular harvesting without reseeding. Two grass species, native to North America and known as colonizers of mine tailings, Andropogon gerardii Vitman (Big bluestem) and Panicum virgatum L. (Switchgrass; Levy et al. 1999), and metal accumulators, were not expected to grow well in the State of Washington. Two other grass species, used for phytoremediation purposes in Europe because of their $\mathrm{Pb}$ accumulating potential, Thlaspi caerulescens and T. ochroleucum, would be amenable to be introduced in North America, and produce a sizable biomass in the order of 10 tonnes $\mathrm{ha}^{-1}$, but were not expected to grow back the next year (McGrath et al. 1997; S. P. McGrath, IACR, Rothamstead, United Kingdom, Pers. Comm. 2001). Another herbaceous species often mentioned as hyperaccumulating metals, i.e., Brassica juncea, was not included 
in the current study, because this species usually has a low biomass at high metal concentrations in the soil (Foye et al. 2001) and it has a short life cycle, making several times harvesting and reseeding per growth season requirements for its use as phytoremediating agent, leading to relatively high costs, concomitant with a high likelihood for metal release from the site in periods between harvesting and new vegetation establishment.

Plant material of Alopecurus pratensis and Festuca rubra var. Badger was purchased as seeds from Comstock Seed, Gardnerville, Nevada. The viability of the seeds was evaluated prior to the plant tests, following procedures described by Best et al. (2003). Germination was optimal in seeds wetted with water, indicating that treatment with germination-stimulating chemicals was superfluous. The seeds were maintained at room temperature before use.

\section{Plant incubation and harvesting}

For each unit, seeds were weighed to the nearest $0.001 \mathrm{~g}(0.207 \mathrm{~g}$ of $A$. pratensis and $0.259 \mathrm{~g}$ of $F$. rubra), and placed on top of $1 \mathrm{~L}$ of the appropriate fresh soil mixture contained in a $2-\mathrm{L}$ polyethylene pot with a $0.0238-\mathrm{m}^{2}$ surface area. The pots were situated following the described experimental design in a greenhouse on the U.S. ERDC-EL grounds in Vicksburg, MS. The substrate surfaces were wetted immediately, covered with transparent plastic saucers, and the plastic saucers under the pots were filled with $500 \mathrm{~mL} \mathrm{RO}$ water to prevent drying of the seeds. Seeded substrates were kept moist for 10 days by spraying with RO water. Subsequently, units were allowed to reach target moisture levels, and were irrigated to maintain these levels. Moisture levels were monitored using a soil moisture probe (Theta Probe Soil Moisture Sensor ML2x, Dynamax, Houston, TX). The length of the incubation period of 49 days (4 May-20 June 2001) was long enough to allow the plants to reach about 30 percent of their maximum biomass, with tissue metal concentrations believed to have reached a steady state. After incubation, plants were harvested completely, divided into shoot and roots, rinsed repeatedly with $\mathrm{RO}$ water to remove adhering soil particles, blotted dry, weighed, and dried. Remaining soils were transferred into 3.8-L plastic bags and stored under refrigeration $\left(5^{\circ} \mathrm{C}\right)$ until further use.

\section{Plant analysis}

Dry weights of the plants were determined by drying in a forced-air oven to constant weight $\left(105^{\circ} \mathrm{C}\right)$. The total metal concentrations were determined in all plant samples, including $\mathrm{Pb}, \mathrm{Zn}, \mathrm{Fe}, \mathrm{Cr}, \mathrm{Ni}$, and $\mathrm{Hg}$. For the analysis of all metals, except $\mathrm{Hg}, 0.3 \mathrm{~g}$ dry plant material was digested in a microwave oven, and analyzed using ICP-ES (see soil analysis). Hg was determined in dry mass, using the cold vapor method (USEPA Method 7471A, USEPA 1994).

\section{Statistics}

The soil mixtures were tested for significant differences in characteristics prior to incubation using Analysis of Variance (ANOVA). The level of 
significance was set at a confidence level of 95 percent ( $p$ value $\leq 0.05)$. The STATGRAPHICS Plus for Windows 3 package (Manugistics, Rockville, MD, 1997) was used for statistical analyses. All soil units were also tested for significant differences in BL-metals and $\mathrm{pH}$ after incubation, using ANOVA.

Plant responses to treatment, in terms of biomass and tissue metal concentration, were tested for significance using ANOVA, followed by Duncan's multiple range test. The Fe data were included in the statistical analyses, but proved not to be significantly influenced by any of the treatments. The Ni data were not included in the statistical analyses because the data set was too small to generate statistically valid outcomes.

Relationships between plant responses and soil characteristics were derived from multiple regression. The final model to fit the data was chosen through stepwise selection with variables remaining in the model if significant at a confidence level of 95 percent $(\mathrm{p} \leq 0.05)$. The $\mathrm{R}^{2}$ value of the regression model, i.e., an indicator of the proportion of the variance explained by the equation, was set at $\geq 0.50$. This means that only regressions explaining at least 50 percent of the variance in the dataset were considered as meaningful. The estimated values of all coefficients in the equations are presented with their associated $p$ values and standard errors; here also the level of significance was set at a $p$ value of $\leq 0.05$, unless indicated otherwise.

The biota to soil accumulation factors (BAFs), a measure for the degree to which metals from soil accumulate in plants, were calculated using these regression equations. 


\section{Results}

\section{Soil}

The $\mathrm{Pb}$ concentration in the soil mixtures ranged from 48 to $346 \mathrm{mg} \mathrm{kg}^{-1} \mathrm{DW}$ (Table 3). The concentrations of two other metals exhibited trends similar to that of $\mathrm{Pb}$, i.e., of $\mathrm{Zn}$ (range 64 to $424 \mathrm{mg} \mathrm{kg} \mathrm{DW}^{-1}$ ) and $\mathrm{Fe}$ (range 14967 to 18467 $\mathrm{mg} \mathrm{kg}{ }^{-1} \mathrm{DW}$ ). Of the latter two metals, only $\mathrm{Zn}$ was present at levels exceeding the Chemical Stressor Concentration Level (CSCL). Several other metals were present at considerable, but relatively constant, levels. Only the $\mathrm{Cr}$ and $\mathrm{Hg}$ concentrations exceeded their respective CSCLs. Thus, besides $\mathrm{Pb}$ and $\mathrm{Zn}$, both $\mathrm{Cr}$ and $\mathrm{Hg}$ may have exerted a toxic influence on the plants. The leachable metal (BL) levels were far lower than the total metal levels (0-0.3 percent of total), with only $\mathrm{Zn}$ and Fe being detectable (Table 3).

$\mathrm{Pb}$ class significantly affected the total concentrations of $\mathrm{Pb}, \mathrm{Zn}$, and $\mathrm{Fe}$, and the BL-metal concentrations of $\mathrm{Zn}$ and $\mathrm{Fe}$ in the soil mixtures prior to incubation (Table 4). Organic matter class affected only the total and BL concentrations of $\mathrm{Pb}$. The interaction between $\mathrm{Pb}$ Class and Organic Matter Class also significantly affected the total concentration of $\mathrm{Pb}$, the total and $\mathrm{BL}$ concentrations of $\mathrm{Zn}$, and the BL concentration of Fe. Organic Matter Class significantly affected the macronutrient concentrations (nitrate- $\mathrm{N}$, infinite sink-P, and total-K; Table 4). $\mathrm{Pb}$-class significantly affected soil-pH (Table 4).

The $\mathrm{BL}$ metal concentrations and $\mathrm{pH}$ in the incubated soils are presented in Table 5. Only the concentrations of $\mathrm{Pb}, \mathrm{Zn}$, and $\mathrm{Fe}$ were detectable. The grand means of the $\mathrm{BL}$-concentrations of $\mathrm{Pb}, \mathrm{Zn}$, and $\mathrm{Fe}$, and of $\mathrm{pH}$ were 0.226 $0.251 \mathrm{mg} \mathrm{kg}^{-1} \mathrm{DW}$ for $\mathrm{Pb}, 0.923-1.450 \mathrm{mg} \mathrm{kg}^{-1} \mathrm{DW}$ for $\mathrm{Zn}, 1.290-2.030 \mathrm{mg} \mathrm{kg}^{-1}$ $\mathrm{DW}$ for $\mathrm{Fe}$, and 5.37-5.38 for $\mathrm{pH}$. The BL-metal concentrations were significantly affected not only by the main factors Plant Species, Pb Class, Organic Matter Class, and Moisture Class, but also by most interactions (Table 6). $\mathrm{pH}$ was significantly affected by Pb Class, Organic Matter Class, and Moisture Class, but not by plant species or any of the interactions (Table 6). Mean values and standard deviations are presented in Appendix A Table. 


\begin{tabular}{|c|c|c|c|c|c|c|c|c|}
\hline \multicolumn{9}{|c|}{$\begin{array}{l}\text { Table } 3 \\
\text { Characteristics of the Soil Mixtures Prior to Incubation }\end{array}$} \\
\hline \multirow[b]{2}{*}{ Characteristic } & \multicolumn{8}{|c|}{ Soil mixture } \\
\hline & $\begin{array}{l}14 \mathrm{OM}^{\mathrm{a}} \\
\mathrm{MB}-\mathrm{Pb}(50)^{\mathrm{b}} \\
\operatorname{Mix} 1\end{array}$ & $\begin{array}{l}14 \mathrm{OM} \\
233 \mathrm{~Pb} \\
\text { Mix } 2\end{array}$ & $\begin{array}{l}14 \mathrm{OM} \\
256 \mathrm{~Pb} \\
\text { Mix } 3\end{array}$ & $\begin{array}{l}14 \mathrm{OM} \\
331 \mathrm{~Pb} \\
\text { Mix } 4\end{array}$ & $\begin{array}{l}20 \text { OM } \\
\text { MB-Pb (50) } \\
\text { Mix } 5\end{array}$ & $\begin{array}{l}20 \mathrm{OM} \\
233 \mathrm{~Pb} \\
\text { Mix } 6\end{array}$ & $\begin{array}{l}20 \mathrm{OM} \\
256 \mathrm{~Pb} \\
\mathrm{Mix} 7\end{array}$ & $\begin{array}{l}20 \mathrm{OM} \\
331 \mathrm{~Pb} \\
\mathrm{Mix} 8\end{array}$ \\
\hline \multicolumn{9}{|c|}{ Total-Metals (mg kg $\left.{ }^{-1} \mathrm{DW}\right)$} \\
\hline Lead & $48.30 \pm 3.01$ & $219.33 \pm 22.81$ & $219.00 \pm 9.54$ & $315.67 \pm 1.15$ & $50.97 \pm 2.65$ & $245.67 \pm 6.35$ & $293.33 \pm 20.31$ & $346.00 \pm 39.85$ \\
\hline Zinc & $63.50 \pm 3.50$ & $156.33 \pm 15.14$ & $228.33 \pm 8.62$ & $424.00 \pm 115.3$ & $65.00 \pm 1$ & $168.67 \pm 6.11$ & $262.67 \pm 17.62$ & $307.33 \pm 35.23$ \\
\hline Chromium & $21.17 \pm 1.18$ & $23.87 \pm 4.00$ & $24.47 \pm 2.99$ & $24.43 \pm 4.94$ & $21.17 \pm 1.12$ & $25.20 \pm 4.85$ & $22.47 \pm 2.31$ & $23.17 \pm 4.32$ \\
\hline Nickel & $18.53 \pm 1.10$ & $21.87 \pm 3.44$ & $21.83 \pm 2.00$ & $21.77 \pm 1.90$ & $19.20 \pm 1.14$ & $20.57 \pm 2.23$ & $19.8 \pm 2.05$ & $19.17 \pm 1.01$ \\
\hline Mercury & $<0.1$ & $0.33 \pm 0.01$ & $0.33 \pm 0.01$ & $0.51 \pm 0.05$ & $<0.1$ & $0.32 \pm 0.02$ & $0.48 \pm 0.03$ & $0.62 \pm 0.03$ \\
\hline Iron & $15233 \pm 551$ & $16967 \pm 1650$ & $17933 \pm 1007$ & $18467 \pm 1950$ & $14967 \pm 115$ & $17167 \pm 1563$ & $16900 \pm 1058$ & $16200 \pm 1300$ \\
\hline \multicolumn{9}{|c|}{ BL-Metals $\left(\mathrm{mg} \mathrm{kg}^{-1} \mathrm{DW}\right)$} \\
\hline Zinc & $0.18 \pm 0.05$ & $0.46 \pm 0.03$ & $0.64 \pm 0.09$ & $0.97 \pm 0.04$ & $0.16 \pm 0.05$ & $0.85 \pm 0.01$ & $0.86 \pm 0.04$ & $1.31 \pm 0.18$ \\
\hline Iron & $1.44 \pm 0.71$ & $1.42 \pm 0.36$ & $1.12 \pm 0.15$ & $0.65 \pm 0.12$ & $3.46 \pm 0.36$ & $0.54 \pm 0.05$ & $0.51 \pm 0.05$ & $0.21 \pm 0.05$ \\
\hline \multicolumn{9}{|c|}{ Nutrients (mg kg $\left.{ }^{-1} \mathrm{DW}\right)$} \\
\hline Nitrate-N & $89.41 \pm 10.93$ & $32.29 \pm 1.04$ & $31.73 \pm 1.61$ & $20.05 \pm 2.02$ & $59.50 \pm 2.19$ & $152.86 \pm 8.47$ & $140.62 \pm 20.29$ & $173.35 \pm 34.2$ \\
\hline Infinite-sink P & $0.95 \pm 0.94$ & $1.72 \pm 0.48$ & $1.85 \pm 0.69$ & $1.52 \pm 0.44$ & $3.33 \pm 2.20$ & $2.19 \pm 0.55$ & $3.24 \pm 1.20$ & $2.12 \pm 0.33$ \\
\hline Total-K & $110.09 \pm 20.15$ & $36.87 \pm 5.54$ & $33.86 \pm 0.71$ & $19.52 \pm 0.65$ & $213.68 \pm 37.36$ & $198.33 \pm 37.78$ & $237.86 \pm 100.6$ & $192.74 \pm 60.99$ \\
\hline \multicolumn{9}{|c|}{ Other } \\
\hline $\mathrm{pH}_{\text {water }}$ & $5.24 \pm 0.04$ & $5.26 \pm 0.01$ & $5.31 \pm 0.01$ & $5.34 \pm 0.00$ & $5.22 \pm 0.06$ & $5.25 \pm 0.01$ & $5.38 \pm 0.01$ & $5.38 \pm 0.00$ \\
\hline OM (\% DW) & $17.88 \pm 1.09$ & $13.56 \pm 2.11$ & $12.24 \pm 0.21$ & $10.52 \pm 0.51$ & $21.85 \pm 2.28$ & $19.5 \pm 3.32$ & $17.88 \pm 0.63$ & $17.85 \pm 3.05$ \\
\hline DW (\% FW) & $73.95 \pm 0.24$ & $76.89 \pm 1.78$ & $77.10 \pm 0.5$ & $77.11 \pm 0.82$ & $68.8 \pm 1.4$ & $69.35 \pm 2.27$ & $70.93 \pm 0.39$ & $69.1 \pm 3.65$ \\
\hline $\mathrm{BD}(\mathrm{g} \mathrm{DW} / \mathrm{mL}$ & $1.15 \pm 0.06$ & $1.37 \pm 0.01$ & $1.40 \pm 0.07$ & $1.33 \pm 0.03$ & $1.06 \pm 0.08$ & $1.12 \pm 0.19$ & $1.05 \pm 0.02$ & $1.15 \pm 0.08$ \\
\hline \multicolumn{9}{|c|}{$\begin{array}{l}\text { Abbreviations: MB, mixture background; FW, fresh weight; BD, bulk density } \\
\text { a Organic matter }(\mathrm{OM}) \text { classes in \%DW } \\
{ }^{b} \mathrm{~Pb} \text { classes in } \mathrm{mg} \mathrm{kg}^{-1} \mathrm{DW} \\
\text { Mean values and standard deviations }(\mathrm{N}=3)\end{array}$} \\
\hline
\end{tabular}

\begin{tabular}{|c|c|c|c|c|}
\hline \multicolumn{5}{|c|}{$\begin{array}{l}\text { Table } 4 \\
\text { Differences in Soil Mixture Parameters Prior to Incubation, as } \\
\text { Tested for Statistical Significance Using ANOVA, Taking Pb Class, } \\
\text { Organic Matter Class, and Their Interaction as Factors }\end{array}$} \\
\hline \multirow[b]{2}{*}{ Factor } & \multicolumn{4}{|c|}{ Statistic } \\
\hline & df & MS & F-ratio & p-value \\
\hline \multicolumn{5}{|c|}{ Total-Metals } \\
\hline \multicolumn{5}{|l|}{ Lead concentration } \\
\hline A. Pb Class & 3 & 85411.0 & 255.38 & $<0.001$ \\
\hline B. Organic Matter Class & 1 & 6669.4 & 19.94 & $<0.001$ \\
\hline $\mathrm{A} \times \mathrm{B}$ Interaction & 3 & 1332.5 & 3.98 & 0.027 \\
\hline \multicolumn{5}{|l|}{ Zinc concentration } \\
\hline A. Pb Class & 3 & 98040.9 & 51.49 & $<0.001$ \\
\hline B. Organic Matter Class & 1 & 1751.4 & 0.92 & 0.352 \\
\hline A x B Interaction & 3 & 6871.3 & 3.61 & 0.037 \\
\hline \multicolumn{5}{|r|}{ (Continuec } \\
\hline
\end{tabular}




\begin{tabular}{|c|c|c|c|c|}
\hline \multicolumn{5}{|l|}{ Table 4 (Concluded) } \\
\hline \multirow[b]{2}{*}{ Factor } & \multicolumn{4}{|c|}{ Statistic } \\
\hline & df & MS & F-ratio & p-value \\
\hline \multicolumn{5}{|l|}{ Iron concentration } \\
\hline A. Pb Class & 3 & $7.211 \times 10^{6}$ & 4.40 & 0.019 \\
\hline B. Organic Matter Class & 1 & $4.250 \times 10^{6}$ & 2.59 & 0.127 \\
\hline $\mathrm{A} \times \mathrm{B}$ Interaction & 3 & $1.741 \times 10^{6}$ & 1.06 & 0.393 \\
\hline \multicolumn{5}{|c|}{ BL-Metals } \\
\hline \multicolumn{5}{|l|}{ Zinc concentration } \\
\hline A. Pb Class & 3 & 0.951 & 151.06 & $<0.001$ \\
\hline B. Organic Matter Class & 1 & 0.319 & 50.76 & $<0.001$ \\
\hline $\mathrm{A} \times \mathrm{B}$ Interaction & 3 & 0.051 & 8.16 & 0.002 \\
\hline \multicolumn{5}{|l|}{ Iron concentration } \\
\hline A. Pb Class & 3 & 4.669 & 46.62 & $<0.001$ \\
\hline B. Organic Matter Class & 1 & 0.003 & 0.03 & 0.860 \\
\hline $\mathrm{A} \times \mathrm{B}$ Interaction & 3 & 2.709 & 27.05 & $<0.001$ \\
\hline \multicolumn{5}{|c|}{ Nutrients } \\
\hline \multicolumn{5}{|l|}{ Nitrate-N concentration } \\
\hline A. Pb Class & 3 & 563.3 & 2.53 & 0.094 \\
\hline B. Organic Matter Class & 1 & 46530.4 & 208.58 & $<0.001$ \\
\hline $\mathrm{A} \times \mathrm{B}$ Interaction & 3 & 9.818 .5 & 44.02 & $<0.001$ \\
\hline \multicolumn{5}{|l|}{ Infinite-sink $\mathrm{P}$ concentration } \\
\hline A. Pb Class & 3 & 0.600 & 0.57 & 0.645 \\
\hline B. Organic Matter Class & 1 & 8.779 & 8.29 & 0.011 \\
\hline$A \times B$ Interaction & 3 & 1.158 & 1.09 & 0.380 \\
\hline \multicolumn{5}{|l|}{ Total $\mathrm{K}$ concentration } \\
\hline A. Pb Class & 3 & 3547.9 & 1.66 & 0.216 \\
\hline B.Organic Matter Class & 1 & 154694.0 & 72.31 & $<0.001$ \\
\hline$A \times B$ Interaction & 3 & 2647.4 & 1.24 & 0.329 \\
\hline \multicolumn{5}{|c|}{ Other } \\
\hline \multicolumn{5}{|l|}{$\mathrm{pH}_{\text {water }}$} \\
\hline A. Pb Class & 3 & 0.024 & 31.24 & $<0.001$ \\
\hline B. Organic Matter Class & 1 & 0.002 & 3.00 & 0.102 \\
\hline $\mathrm{A} \times \mathrm{B}$ Interaction & 3 & 0.002 & 3.09 & 0.057 \\
\hline
\end{tabular}

\begin{tabular}{|c|c|c|}
\hline \multicolumn{3}{|c|}{$\begin{array}{l}\text { Table } 5 \\
\text { Leachable Metal Fractions and pH in Soil Mixtures After 49-d } \\
\text { Incubation with A. pratensis and F. rubra }\end{array}$} \\
\hline Plant Species/Soil parameter & A. pratensis & F. rubra \\
\hline \multicolumn{3}{|c|}{ BL-Metals (mg kg $\left.{ }^{-1} \mathrm{DW}\right)$} \\
\hline Lead concentration & $0.251 \pm 0.096$ & $0.226 \pm 0.073$ \\
\hline Zinc concentration & $0.923 \pm 0.712$ & $1.450 \pm 1.906$ \\
\hline Iron concentration & $2.03 \pm 2.25$ & $1.290 \pm 1.043$ \\
\hline \multicolumn{3}{|c|}{ Other } \\
\hline $\mathrm{pH}_{\text {water }}$ & $5.37 \pm 0.06$ & $5.38 \pm 0.05$ \\
\hline
\end{tabular}




\begin{tabular}{|c|c|c|c|c|}
\hline \multicolumn{5}{|c|}{$\begin{array}{l}\text { Table } 6 \\
\text { Differences in Soil Mixture Parameters After 49-d Incubation with } \\
\text { A. pratensis and F. rubra, as Tested for Statistical Significance } \\
\text { Using ANOVA, Taking Species, Pb Class, Organic Matter Class, } \\
\text { Moisture Class, and Their Interactions as Factors, and Block as } \\
\text { Covariate* }\end{array}$} \\
\hline \multirow[b]{2}{*}{ Factor } & \multicolumn{4}{|c|}{ Statistic } \\
\hline & df & MS & F-ratio & $p$-value \\
\hline \multicolumn{5}{|c|}{ BL-Metals } \\
\hline \multicolumn{5}{|l|}{ Lead concentration } \\
\hline A. Species & 1 & 0.019 & 8.27 & 0.005 \\
\hline B. Pb Class & 3 & 0.041 & 17.47 & $<0.001$ \\
\hline C. Organic Matter Class & 1 & 0.142 & 60.46 & $<0.001$ \\
\hline D. Moisture Class & 1 & 0.079 & 33.89 & $<0.001$ \\
\hline$A \times C$ Interaction & 1 & 0.028 & 11.68 & $<0.001$ \\
\hline $\mathrm{B} \times \mathrm{C}$ Interaction & 3 & 0.042 & 17.64 & $<0.001$ \\
\hline $\mathrm{C} \times \mathrm{D}$ Interaction & 1 & 0.042 & 17.78 & $<0.001$ \\
\hline $\mathrm{B} \times \mathrm{C} \times \mathrm{D}$ Interaction & 3 & 0.007 & 3.07 & 0.032 \\
\hline$A \times B \times C \times D$ Interaction & 6 & 0.012 & 4.92 & $<0.001$ \\
\hline \multicolumn{5}{|l|}{ Zinc concentration } \\
\hline A. Species & 1 & 8.88 & 7.92 & 0.006 \\
\hline B. Pb Class & 3 & 14.02 & 12.51 & $<0.001$ \\
\hline C. Organic Matter Class & 1 & 31.94 & 28.50 & $<0.001$ \\
\hline D. Moisture Class & 1 & 6.33 & 5.65 & 0.020 \\
\hline $\mathrm{B} \times \mathrm{C}$ Interaction & 3 & 5.360 & 4.78 & 0.004 \\
\hline $\mathrm{B} \times \mathrm{C} \times \mathrm{D}$ Interaction & 3 & 3.374 & 3.01 & 0.034 \\
\hline$A \times B \times C \times D$ Interaction & 6 & 2.621 & 2.34 & 0.038 \\
\hline \multicolumn{5}{|l|}{ Iron concentration } \\
\hline A. Species & 1 & 8.39 & 32.25 & $<0.001$ \\
\hline B. Pb Class & 3 & 3.83 & 14.73 & $<0.001$ \\
\hline C. Organic Matter Class & 1 & 118.90 & 456.86 & $<0.001$ \\
\hline D. Moisture Class & 1 & 11.03 & 42.37 & $<0.001$ \\
\hline$A \times C$ Interaction & 1 & 5.11 & 19.64 & $<0.001$ \\
\hline $\mathrm{B} \times \mathrm{C}$ Interaction & 3 & 5.26 & 20.24 & $<0.001$ \\
\hline $\mathrm{C} \times \mathrm{D}$ Interaction & 1 & 3.57 & 13.70 & $<0.001$ \\
\hline \multicolumn{5}{|c|}{ Other } \\
\hline \multicolumn{5}{|l|}{$\mathrm{pH}_{\text {water }}$} \\
\hline A. Species & 1 & 0.005 & 1.71 & 0.194 \\
\hline B. Pb Class & 3 & 0.011 & 3.70 & 0.014 \\
\hline C. Organic Matter Class & 1 & 0.012 & 4.29 & 0.041 \\
\hline D. Moisture Class & 1 & 0.016 & 5.54 & 0.021 \\
\hline
\end{tabular}

The total and BL-metal quantities per ha were estimated, based on the assumption that the metal contamination at Fort Lewis was largely concentrated in the upper $33 \mathrm{~cm}$ soil surface, i.e., the depth up to which the tested soil was excavated. The total-metal quantities were derived from the total-metal 
concentrations, by multiplication with a factor of $38.8 \times 10^{4}$. This factor was calculated using the following data: pot contents were $1 \mathrm{~L}$ fresh soil, with a DW content of 72 percent, bulk density of $1.2 \mathrm{~g} \mathrm{DW} \mathrm{mL}^{-1}$ (cf. Table 3), and a surface area of $0.0238 \mathrm{~m}^{2}$. The BL-metal quantities were derived likewise, from the BLmetal concentrations. Thus it was found that the leachable quantities of metals were (Table 7)

- below detection prior to incubation, and maximally $0.15 \mathrm{~kg} \mathrm{~Pb} \mathrm{ha}^{-1}$ after incubation

- maximally $0.48 \mathrm{~kg} \mathrm{Zn} \mathrm{ha}^{-1}$ prior to incubation, and $2.00 \mathrm{~kg} \mathrm{Zn} \mathrm{ha}^{-1}$ after incubation

- $\quad 1.27 \mathrm{~kg} \mathrm{Fe} \mathrm{ha}^{-1}$ before and after incubation.

\section{Table 7 \\ Leachable Metal Quantities Prior to and After 49-d Incubation with A. pratensis and F. rubra*}

\begin{tabular}{|c|c|c|c|c|c|c|c|c|}
\hline \multirow{3}{*}{ Characteristic } & \multicolumn{8}{|c|}{ Soil mixture } \\
\hline & \multicolumn{4}{|c|}{$14 \%$ Organic Matter Class } & \multicolumn{4}{|c|}{$20 \%$ Organic Matter Class } \\
\hline & MB-Pb & $233 \mathrm{~Pb}$ & $256 \mathrm{~Pb}$ & $331 \mathrm{~Pb}$ & MB-Pb & $233 \mathrm{~Pb}$ & $256 \mathrm{~Pb}$ & $331 \mathrm{~Pb}$ \\
\hline \multicolumn{9}{|c|}{ Prior to Incubation } \\
\hline BL-Zinc & 0.09 & 0.23 & 0.32 & 0.49 & 0.08 & 0.43 & 0.43 & 0.66 \\
\hline BL-Iron & 0.73 & 0.72 & 0.57 & 0.33 & 1.74 & 0.27 & 0.26 & 0.11 \\
\hline \multicolumn{9}{|c|}{ After Incubation With Vegetation } \\
\hline \multicolumn{9}{|c|}{ A. pratensis } \\
\hline \multicolumn{9}{|c|}{$10 \%$ Moisture Class } \\
\hline BL-Lead & 0.09 & 0.12 & 0.10 & 0.22 & 0.10 & 0.20 & 0.20 & 0.19 \\
\hline BL-Zinc & $0.11(+22)$ & $0.22(-4)$ & $0.31(-3)$ & $0.65(+32)$ & $0.08(0)$ & $0.22(-50)$ & $0.34(-21)$ & $0.53(-20)$ \\
\hline BL-Iron & $0.58(-31)$ & $1.69(+135)$ & $1.16(+104)$ & $1.54(+360)$ & $1.43(-18)$ & $2.33(+763)$ & $1.73(+565)$ & $1.50(+1260)$ \\
\hline \multicolumn{9}{|c|}{$40 \%$ Moisture Class } \\
\hline BL-Lead & 0.10 & 0.10 & 0.10 & 0.10 & 0.11 & 0.11 & 0.10 & 0.10 \\
\hline BL-Zinc & $0.12(+33)$ & $0.52(+126)$ & $0.75(+134)$ & $1.35(+175)$ & $0.13(+63)$ & $0.34(-21)$ & $0.72(+67)$ & $1.04(+57)$ \\
\hline BL-Iron & $0.39(-47)$ & $0.23(-68)$ & $0.25(-56)$ & $0.13(-60)$ & $0.60(-65)$ & $0.60(-122)$ & $0.20(-23)$ & $0.17(+55)$ \\
\hline \multicolumn{9}{|c|}{ F. rubra } \\
\hline \multicolumn{9}{|c|}{$10 \%$ Moisture Class } \\
\hline BL-Lead & 0.09 & 0.09 & 0.10 & 0.12 & 0.10 & 0.13 & 0.14 & 0.21 \\
\hline BL-Zinc & $0.54(+500)$ & $0.24(+4)$ & $0.40(+25)$ & $0.60(+22)$ & $0.11(+38)$ & $0.25(-42)$ & $0.39(-10)$ & $0.54(+22)$ \\
\hline BL-Iron & $0.46(-37)$ & $1.05(+46)$ & $0.86(+51)$ & $0.91(+176)$ & $0.71(-60)$ & $1.60(+193)$ & $1.65(+535)$ & $1.04(+845)$ \\
\hline \multicolumn{9}{|c|}{$40 \%$ Moisture Class } \\
\hline BL-Lead & 0.10 & 0.10 & 0.10 & 0.10 & 0.11 & 0.11 & 0.11 & 0.11 \\
\hline BL-Zinc & $0.17(+89)$ & $2.74(+1091)$ & $1.12(+250)$ & $1.53(+212)$ & $0.16(+100)$ & $0.44(+2)$ & $0.75(+74)$ & $1.72(+160)$ \\
\hline BL-Iron & $0.29(-60)$ & $0.25(-65)$ & $0.14(-75)$ & $0.15(-55)$ & $0.40(-77)$ & $0.38(+40)$ & $0.28(+8)$ & $0.22(+100)$ \\
\hline
\end{tabular}




\section{Plants}

Plant biomass significantly differed between species. A. pratensis produced about twice as much biomass as $F$. rubra, i.e., 546 versus $249 \mathrm{~g} \mathrm{DW} \mathrm{m}^{-2}$ (Table 8). Shoot and root biomass significantly decreased with increasing $\mathrm{Pb}$ Class (Tables 8 and 9). In A. pratensis shoot biomass decreased from 134 to $73 \mathrm{~g}$ $\mathrm{DW} \mathrm{m}{ }^{-2}$, and root biomass from 488 to $320 \mathrm{~g} \mathrm{DW} \mathrm{m}^{-2}$. In F. rubra shoot biomass decreased from 87 to 57 , and root biomass from 251 to $83 \mathrm{~g} \mathrm{DW} \mathrm{m}^{-2}$. A. pratensis produced relatively more root mass than $F$. rubra, the shoot:root ratios being 0.21 in the former and 0.39 in the latter (Table 8). Shoot biomass of $A$. pratensis increased and root biomass decreased with increasing organic matter class (shoots: from 69 to $123 \mathrm{~g} \mathrm{DW} \mathrm{m}^{-2}$, roots from 547 to $355 \mathrm{~g} \mathrm{DW} \mathrm{m}^{-2}$ ) and both shoot and root biomass increased with increasing moisture class (shoots: from 84 to $109 \mathrm{~g} \mathrm{DW} \mathrm{m}^{-2}$, roots from 252 to $650 \mathrm{~g} \mathrm{DW} \mathrm{m}^{-2}$; Tables 8 and 9). Both shoot and root biomass of $F$. rubra increased with increasing organic matter and moisture class (organic matter class, shoots: from 55 to $85 \mathrm{~g} \mathrm{DW} \mathrm{m}^{-2}$, roots: from 177 to $181 \mathrm{~g} \mathrm{DW} \mathrm{m}^{-2}$; moisture class, shoots: from 61 to $79 \mathrm{~g} \mathrm{DW} \mathrm{m}^{-2}$, roots: from 131 to $227 \mathrm{~g} \mathrm{DW} \mathrm{m}^{-2}$; Tables 8 and 9). From the ANOVA it became clear that not only the main factors, Plant Species, Pb Class, Organic Matter Class, and Moisture Class, but also up to five of the interactions between the main factors, significantly affected plant biomass (Table 9). The shoot, root, and plant biomass in relation to the relevant soil-metal concentrations were plotted for each Organic Matter-Moisture Class combination (Figures 3 to 6).

It was conspicuous that $\mathrm{Pb}$ accumulated to a lesser extent than $\mathrm{Zn}$, despite the fact that both metals were present at similar concentrations in the soil mixtures and both metals have similar CSCL levels (Table 3, Table 10). A. pratensis accumulated more metals per kg DW than F. rubra (Table 10). The Pb concentration was below detection in most shoots, but it increased significantly in the roots with increasing soil- $\mathrm{Pb}$ Class. For $A$. pratensis the $\mathrm{Pb}$ concentration increased from 34 to $288 \mathrm{mg} \mathrm{kg}^{-1} \mathrm{DW}$ in roots, and for $F$. rubra from 27 to $248 \mathrm{mg} \mathrm{kg}^{-1} \mathrm{DW}$. The $\mathrm{Zn}$ concentration increased in shoots and roots with increasing Pb Class. In A. pratensis it increased from 44 to $260 \mathrm{mg} \mathrm{Zn} \mathrm{kg}^{-1} \mathrm{DW}$ in shoots, and from 123 to $744 \mathrm{mg} \mathrm{Zn} \mathrm{kg}^{-1} \mathrm{DW}$ in roots. In F. rubra it increased from 39 to $111 \mathrm{mg} \mathrm{Zn} \mathrm{kg}^{-1} \mathrm{DW}$ in shoots, and from 88 to $566 \mathrm{mg} \mathrm{Zn} \mathrm{kg}{ }^{-1} \mathrm{DW}$ in roots. The tissue- $\mathrm{Pb}$ and $-\mathrm{Zn}$ concentrations in relation to the relevant soil-metal concentrations were plotted for each Organic Matter-Moisture Class combination (Figures 7 to 10 ). 


\begin{tabular}{|c|c|c|}
\hline \multicolumn{3}{|c|}{$\begin{array}{l}\text { Table } 8 \\
\text { Biomass of Whole Plants, Shoots, and Roots of } A \text {. pratensis and } \\
\text { F. rubra After } 49-\text { d Incubation, Listed by Treatment for Each Plant } \\
\text { Compartment }\end{array}$} \\
\hline Species/Treatment & A. pratensis & F. rubra \\
\hline \multicolumn{3}{|c|}{ Whole plant biomass $\left(\mathrm{g} \mathrm{DW} \mathrm{m}^{-2}\right)$} \\
\hline Grand mean & $545.77 \pm 404.21$ & $249.07 \pm 159.24$ \\
\hline \multicolumn{3}{|l|}{ Pb Class } \\
\hline $50 \mathrm{mg} \mathrm{kg}^{-1} \mathrm{DW}$ & $622.43 \pm 368.84$ & $338.25 \pm 161.30$ \\
\hline $233 \mathrm{mg} \mathrm{kg}^{-1} \mathrm{DW}$ & $655.45 \pm 633.10$ & $308.86 \pm 193.73$ \\
\hline $256 \mathrm{mg} \mathrm{kg}^{-1} \mathrm{DW}$ & $515.03 \pm 265.48$ & $209.64 \pm 112.25$ \\
\hline $331 \mathrm{mg} \mathrm{kg}^{-1} \mathrm{DW}$ & $390.19 \pm 181.54$ & $139.53 \pm 60.10$ \\
\hline \multicolumn{3}{|l|}{ Organic Matter Class } \\
\hline $14 \% \mathrm{DW}$ & $613.75 \pm 540.03$ & $232.09 \pm 131.98$ \\
\hline $20 \% \mathrm{DW}$ & $477.79 \pm 175.71$ & $266.06 \pm 183.09$ \\
\hline \multicolumn{3}{|l|}{ Moisture Class } \\
\hline $10 \% \mathrm{DW}$ & $332.65 \pm 160.67$ & $192.16 \pm 97.21$ \\
\hline $40 \% \mathrm{DW}$ & $758.89 \pm 460.93$ & $305.98 \pm 188.15$ \\
\hline \multicolumn{3}{|c|}{ Shoot biomass (g DW $\mathrm{m}^{-2}$ ) } \\
\hline Grand mean & $96.33 \pm 43.95$ & $70.02 \pm 29.53$ \\
\hline \multicolumn{3}{|l|}{ Pb Class } \\
\hline $50 \mathrm{mg} \mathrm{kg}^{-1} \mathrm{DW}$ & $134.06 \pm 31.47$ & $86.81 \pm 29.37$ \\
\hline $233 \mathrm{mg} \mathrm{kg}^{-1} \mathrm{DW}$ & $95.43 \pm 37.38$ & $73.41 \pm 24.74$ \\
\hline $256 \mathrm{mg} \mathrm{kg}^{-1} \mathrm{DW}$ & $82.92 \pm 40.75$ & $63.23 \pm 26.03$ \\
\hline $331 \mathrm{mg} \mathrm{kg}^{-1} \mathrm{DW}$ & $72.90 \pm 42.04$ & $56.63 \pm 30.93$ \\
\hline \multicolumn{3}{|l|}{ Organic Matter Class } \\
\hline $14 \% \mathrm{DW}$ & $69.43 \pm 39.13$ & $54.62 \pm 2387$ \\
\hline $20 \% \mathrm{DW}$ & $123.22 \pm 30.01$ & $85.42 \pm 26.69$ \\
\hline \multicolumn{3}{|l|}{ Moisture Class } \\
\hline $10 \% \mathrm{DW}$ & $83.51 \pm 36.06$ & $61.48 \pm 17.91$ \\
\hline $40 \% \mathrm{DW}$ & $109.14 \pm 47.82$ & $78.56 \pm 36.06$ \\
\hline \multicolumn{3}{|c|}{ Root biomass $\left(\mathrm{g} \mathrm{DW} \mathrm{m}^{-2}\right)$} \\
\hline Grand mean & $450.98 \pm 397.63$ & $179.05 \pm 143.07$ \\
\hline \multicolumn{3}{|l|}{$\mathrm{Pb}$ Class } \\
\hline $50 \mathrm{mg} \mathrm{kg}^{-1} \mathrm{DW}$ & $488.36 \pm 350.82$ & $251.43 \pm 145.33$ \\
\hline $233 \mathrm{mg} \mathrm{kg}^{-1} \mathrm{DW}$ & $560.03 \pm 638.39$ & $235.45 \pm 176.84$ \\
\hline $256 \mathrm{mg} \mathrm{kg}^{-1} \mathrm{DW}$ & $435.77 \pm 267.47$ & $146.41 \pm 102.64$ \\
\hline $331 \mathrm{mg} \mathrm{kg}^{-1} \mathrm{DW}$ & $319.78 \pm 170.65$ & $82.92 \pm 55.42$ \\
\hline \multicolumn{3}{|l|}{ Organic Matter Class } \\
\hline $14 \% \mathrm{DW}$ & $547.39 \pm 526.40$ & $177.47 \pm 121.64$ \\
\hline $20 \% \mathrm{DW}$ & $354.57 \pm 158.23$ & $180.64 \pm 163.70$ \\
\hline \multicolumn{3}{|l|}{ Moisture Class } \\
\hline $10 \% \mathrm{DW}$ & $252.21 \pm 146.60$ & $130.69 \pm 86.73$ \\
\hline $40 \% \mathrm{DW}$ & $649.75 \pm 467.18$ & $227.42 \pm 171.02$ \\
\hline
\end{tabular}




\begin{tabular}{|c|c|c|c|c|}
\hline \multicolumn{5}{|c|}{$\begin{array}{l}\text { Table } 9 \\
\text { Differences in Plant Biomass Parameters After 49-d Incubation, as } \\
\text { Tested for Statistical Significance Using ANOVA, Taking Species, } \\
\text { Pb Class, Organic Matter Class, Moisture Class, and Their } \\
\text { Interactions as Factors, and Block as Covariate* }\end{array}$} \\
\hline \multirow[b]{2}{*}{ Factor } & \multicolumn{4}{|c|}{ Statistic } \\
\hline & df & MS & F-ratio & p-value \\
\hline \multicolumn{5}{|l|}{ Whole plant biomass } \\
\hline A. Species & 1 & 2795048 & 65.29 & $<0.001$ \\
\hline B. Pb Class & 3 & 339388 & 7.93 & $<0.001$ \\
\hline C. Organic Matter Class & 1 & 86711 & 2.03 & 0.1579 \\
\hline D. Moisture Class & 1 & 2265296 & 52.92 & $<0.001$ \\
\hline$A \times C$ & 1 & 235138 & 5.49 & 0.021 \\
\hline$A \times D$ & 1 & 751793 & 17.56 & $<0.001$ \\
\hline$B \times D$ & 3 & 136762 & 3.19 & 0.027 \\
\hline$C \times D$ & 1 & 342004 & 7.99 & 0.006 \\
\hline$A \times C \times D$ & 1 & 1008961 & 23.57 & $<0.001$ \\
\hline \multicolumn{5}{|l|}{ Shoot biomass } \\
\hline A. Species & 1 & 21749 & 72.04 & $<0.001$ \\
\hline B. Pb Class & 3 & 12421 & 41.14 & $<0.001$ \\
\hline C. Organic Matter Class & 1 & 56229 & 186.24 & $<0.001$ \\
\hline D. Moisture Class & 1 & 14327 & 47.45 & $<0.001$ \\
\hline$A \times B$ & 3 & 1575 & 5.22 & 0.002 \\
\hline$A \times C$ & 1 & 4152 & 13.75 & $<0.001$ \\
\hline$B \times C$ & 3 & 3601 & 11.93 & $<0.001$ \\
\hline$C \times D$ & 1 & 6890 & 22.82 & $<0.001$ \\
\hline \multicolumn{5}{|l|}{ Root biomass } \\
\hline A. Species & 1 & 2323688 & 55.91 & $<0.001$ \\
\hline B. Pb Class & 3 & 244569 & 5.88 & 0.001 \\
\hline C. Organic Matter Class & 1 & 282591 & 6.80 & 0.011 \\
\hline D. Moisture Class & 1 & 1919318 & 46.18 & $<0.001$ \\
\hline$A \times C$ & 1 & 301780 & 7.26 & 0.008 \\
\hline$A \times D$ & 1 & 710828 & 17.10 & $<0.001$ \\
\hline$B \times D$ & 3 & 131083 & 3.15 & 0.028 \\
\hline$C \times D$ & 1 & 445977 & 10.73 & 0.002 \\
\hline$A \times C \times D$ & 1 & 943292 & 22.70 & $<0.001$ \\
\hline
\end{tabular}




\begin{tabular}{|c|c|c|c|c|}
\hline \multicolumn{5}{|c|}{$\begin{array}{l}\text { Table } 10 \\
\text { Pb and Zn Concentrations in Whole Plants, Shoots, and Roots of } \\
\text { A. pratensis and F. rubra After 49-d Incubation, Listed by Treatment } \\
\text { for Each Plant Compartment* }\end{array}$} \\
\hline \multirow{2}{*}{ Species/Treatment } & \multicolumn{2}{|c|}{ A. pratensis } & \multicolumn{2}{|c|}{ F. rubra } \\
\hline & $\mathrm{Pb}$ & $\mathrm{Zn}$ & $\mathrm{Pb}$ & $\mathrm{Zn}$ \\
\hline \multicolumn{5}{|c|}{ Whole plant metal $\left(\mathrm{mg} \mathrm{kg}^{-1} \mathrm{DW}\right)$} \\
\hline Grand mean & $140.95 \pm 153.27$ & $346.17 \pm 223.62$ & $83.47 \pm 87.54$ & $213.05 \pm 124.57$ \\
\hline \multicolumn{5}{|l|}{$\mathrm{Pb}$ Class } \\
\hline $50 \mathrm{mg} \mathrm{kg}^{-1} \mathrm{DW}$ & $24.92 \pm 4.88$ & $101.52 \pm 24.16$ & $22.04 \pm 5.51$ & $73.04 \pm 13.64$ \\
\hline $233 \mathrm{mg} \mathrm{kg}^{-1} \mathrm{DW}$ & $127.89 \pm 142.38$ & $240.36 \pm 73.02$ & $69.81 \pm 25.63$ & $170.24 \pm 45.72$ \\
\hline $256 \mathrm{mg} \mathrm{kg}^{-1} \mathrm{DW}$ & $170.07 \pm 193.41$ & $402.65 \pm 106.63$ & $88.21 \pm 42.12$ & $240.17 \pm 64.64$ \\
\hline $331 \mathrm{mg} \mathrm{kg}^{-1} \mathrm{DW}$ & $241.01 \pm 121.81$ & $640.16 \pm 146.12$ & $152.97 \pm 140.95$ & $366.08 \pm 96.32$ \\
\hline \multicolumn{5}{|l|}{ Organic Matter Class } \\
\hline $14 \% \mathrm{DW}$ & $188.25 \pm 189.26$ & $314.18 \pm 205.91$ & $105.45 \pm 112.44$ & $229.54 \pm 137.58$ \\
\hline $20 \% \mathrm{DW}$ & $93.70 \pm 85.49$ & $378.17 \pm 238.99$ & $62.17 \pm 46.26$ & $197.07 \pm 110.28$ \\
\hline \multicolumn{5}{|l|}{ Moisture Class } \\
\hline $10 \% \mathrm{DW}$ & $121.22 \pm 122.40$ & $292.52 \pm 183.80$ & $92.77 \pm 112.30$ & $217.65 \pm 138.78$ \\
\hline $40 \% \mathrm{DW}$ & $160.73 \pm 178.76$ & $399.82 \pm 248.80$ & $73.87 \pm 51.16$ & $208.30 \pm 110.00$ \\
\hline \multicolumn{5}{|c|}{ Shoot metal $\left(\mathrm{mg} \mathrm{kg}^{-1} \mathrm{DW}\right)$} \\
\hline Grand mean & $9.38 \pm 2.90$ & $131.09 \pm 86.18$ & $8.54 \pm 0.87$ & $67.11 \pm 30.56$ \\
\hline \multicolumn{5}{|l|}{$\mathrm{Pb}$ Class } \\
\hline $50 \mathrm{mg} \mathrm{kg}^{-1} \mathrm{DW}$ & $8.33 \pm 0.00$ & $44.38 \pm 5.61$ & $8.33 \pm 1.74$ & $38.65 \pm 12.19$ \\
\hline $233 \mathrm{mg} \mathrm{kg}^{-1} \mathrm{DW}$ & $8.55+2.08$ & $87.50 \pm 14.66$ & $8.65 \pm 1.25$ & $51.67 \pm 6.50$ \\
\hline $256 \mathrm{mg} \mathrm{kg}^{-1} \mathrm{DW}$ & $8.75 \pm 1.67$ & $132.71+15.82$ & $8.33+1.74$ & $66.88 \pm 9.09$ \\
\hline $331 \mathrm{mg} \mathrm{kg}^{-1} \mathrm{DW}$ & $11.65 \pm 4.61$ & $259.79+54.55$ & $8.85 \pm 1.17$ & $111.25 \pm 21.24$ \\
\hline \multicolumn{5}{|l|}{ Organic Matter Class } \\
\hline $14 \% \mathrm{DW}$ & $14.48 \pm 12.74$ & $144.43 \pm 101.32$ & $8.39 \pm 0.29$ & $65.83 \pm 32.49$ \\
\hline $20 \% \mathrm{DW}$ & $11.27 \pm 4.14$ & $117.76 \pm 66.78$ & $8.70 \pm 1.18$ & $68.39 \pm 28.95$ \\
\hline \multicolumn{5}{|l|}{ Moisture Class } \\
\hline $10 \% \mathrm{DW}$ & $9.58 \pm 3.39$ & $128.28 \pm 85.67$ & $8.33 \pm 0.00$ & $64.32 \pm 27.99$ \\
\hline $40 \% \mathrm{DW}$ & $9.16 \pm 2.36$ & $133.91 \pm 87.95$ & $8.73 \pm 1.30$ & $69.90 \pm 33.14$ \\
\hline \multicolumn{5}{|c|}{ Root metal (mg kg-1 DW) } \\
\hline Grand mean & $168.12 \pm 171.01$ & $407.28 \pm 269.24$ & $125.22 \pm 125.38$ & $306.85 \pm 184.28$ \\
\hline \multicolumn{5}{|l|}{$\mathrm{Pb}$ Class } \\
\hline $50 \mathrm{mg} \mathrm{kg}^{-1} \mathrm{DW}$ & $33.52 \pm 6.81$ & $123.09 \pm 23.96$ & $27.15 \pm 5.57$ & $87.70 \pm 18.34$ \\
\hline $233 \mathrm{mg} \mathrm{kg}^{-1} \mathrm{DW}$ & $159.19 \pm 178.29$ & $288.02 \pm 102.01$ & $96.18 \pm 30.93$ & $223.89 \pm 50.49$ \\
\hline $256 \mathrm{mg} \mathrm{kg}^{-1} \mathrm{DW}$ & $191.33 \pm 198.10$ & $473.64 \pm 157.60$ & $127.74 \pm 40.84$ & $344.48 \pm 39.16$ \\
\hline $331 \mathrm{mg} \mathrm{kg}^{-1} \mathrm{DW}$ & $288.44 \pm 127.74$ & $744.38 \pm 203.53$ & $248.01 \pm 187.58$ & $566.15 \pm 69.15$ \\
\hline \multicolumn{5}{|l|}{ Organic Matter Class } \\
\hline $14 \% \mathrm{DW}$ & $207.43 \pm 203.84$ & $331.27 \pm 207.83$ & $142.84 \pm 158.90$ & $294.60 \pm 179.36$ \\
\hline $20 \% \mathrm{DW}$ & $128.81 \pm 121.20$ & $483.30 \pm 303.64$ & $108.16 \pm 79.96$ & $318.72 \pm 191.03$ \\
\hline \multicolumn{5}{|l|}{ Moisture Class } \\
\hline $10 \% \mathrm{DW}$ & $145.90 \pm 133.83$ & $344.07 \pm 221.34$ & $136.67 \pm 159.79$ & $306.00 \pm 187.15$ \\
\hline $40 \% \mathrm{DW}$ & $190.34 \pm 210.25$ & $470.50 \pm 300.14$ & $113.41 \pm 76.29$ & $307.73 \pm 184.36$ \\
\hline
\end{tabular}




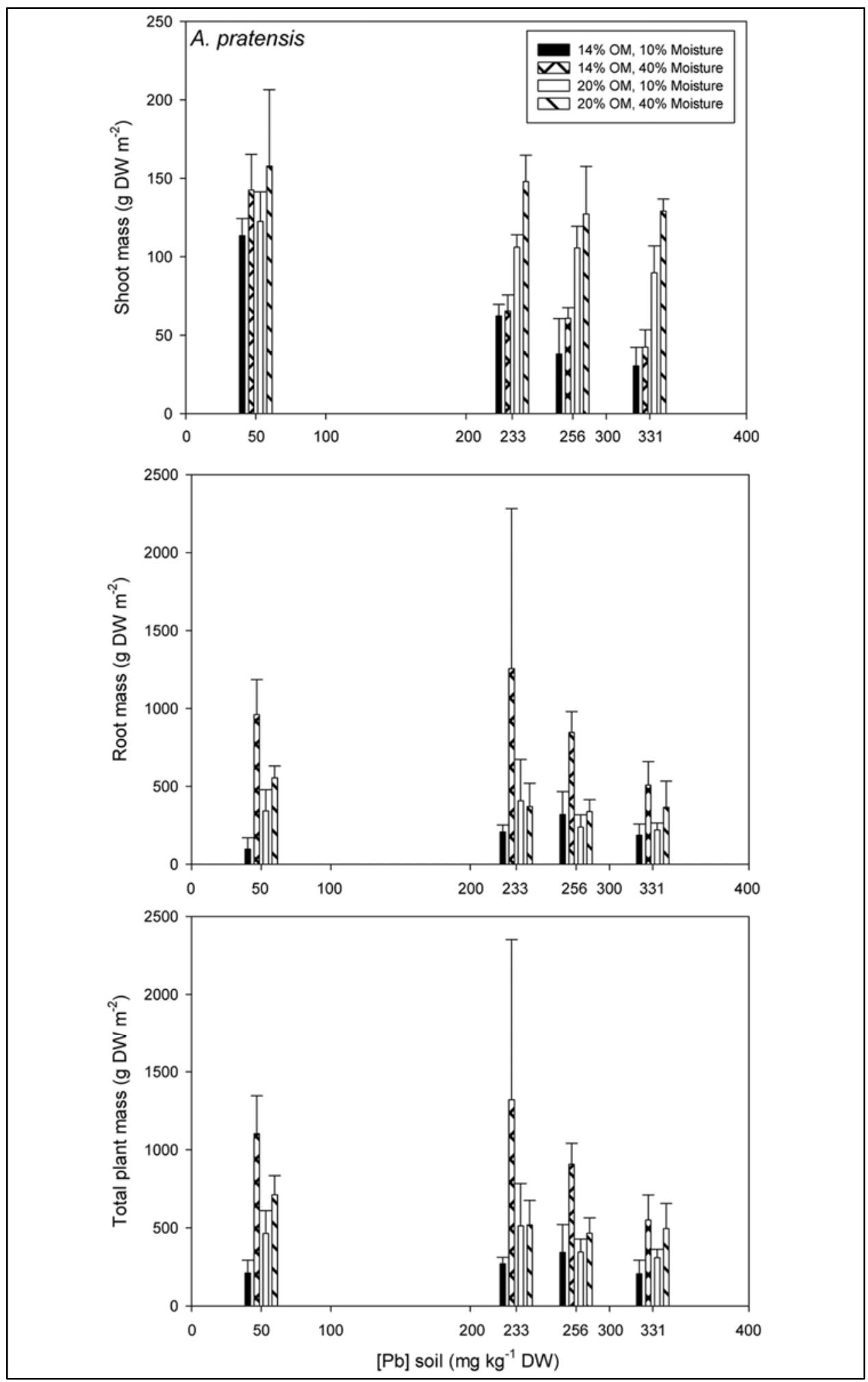

Figure 3. Shoot, root, and total plant mass produced by A. pratensis in 49 days in relation to soil lead concentration. Mean values and standard deviations $(\mathrm{N}=4)$ 


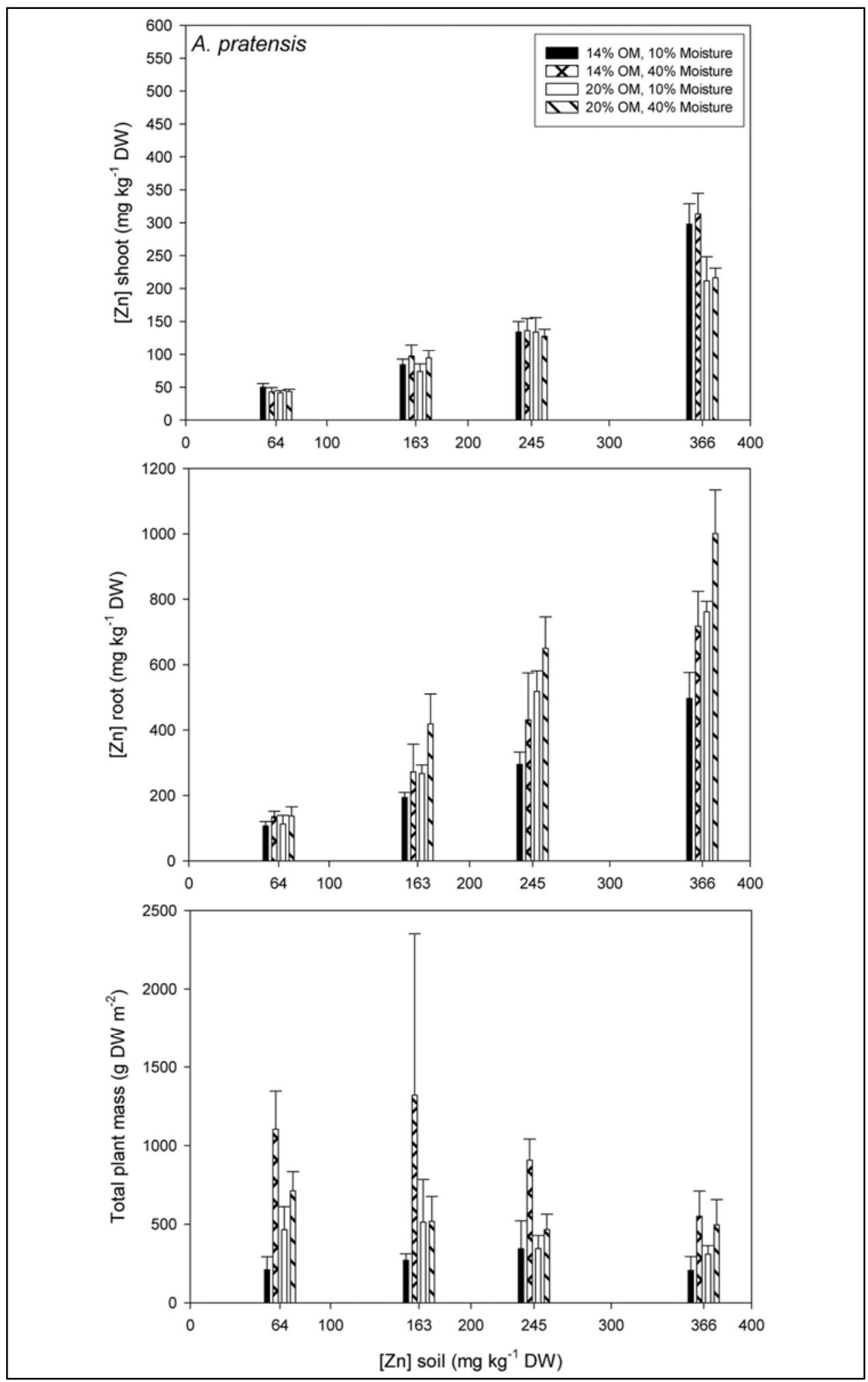

Figure 4. Shoot, root, and total plant mass produced by A. pratensis in 49 days in relation to soil zinc concentration. Mean values and standard deviations $(\mathrm{N}=4)$ 


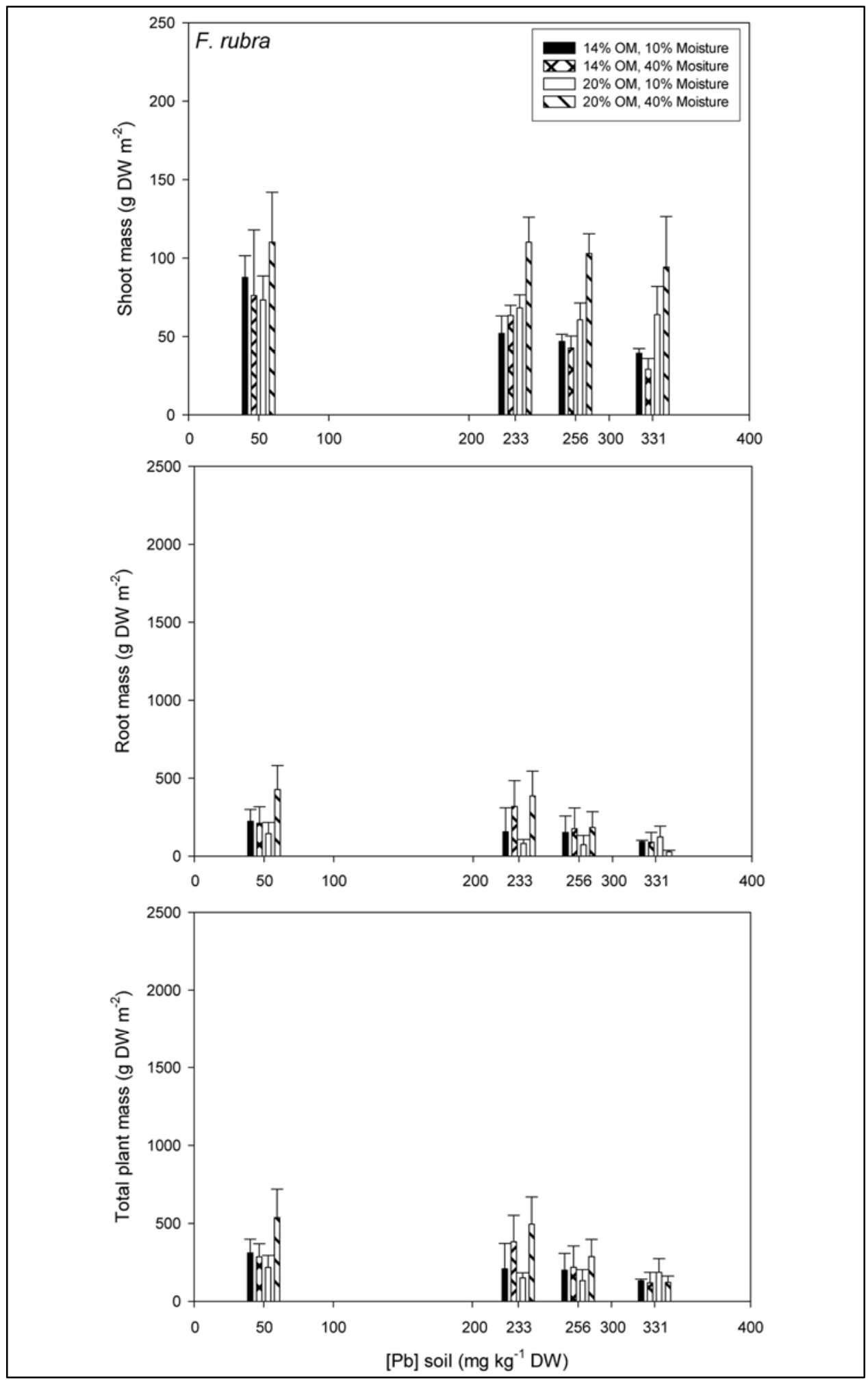

Figure 5. Shoot, root, and total plant mass produced by F. rubra in 49 days in relation to soil lead concentration. Mean values and standard deviations $(\mathrm{N}=4)$ 


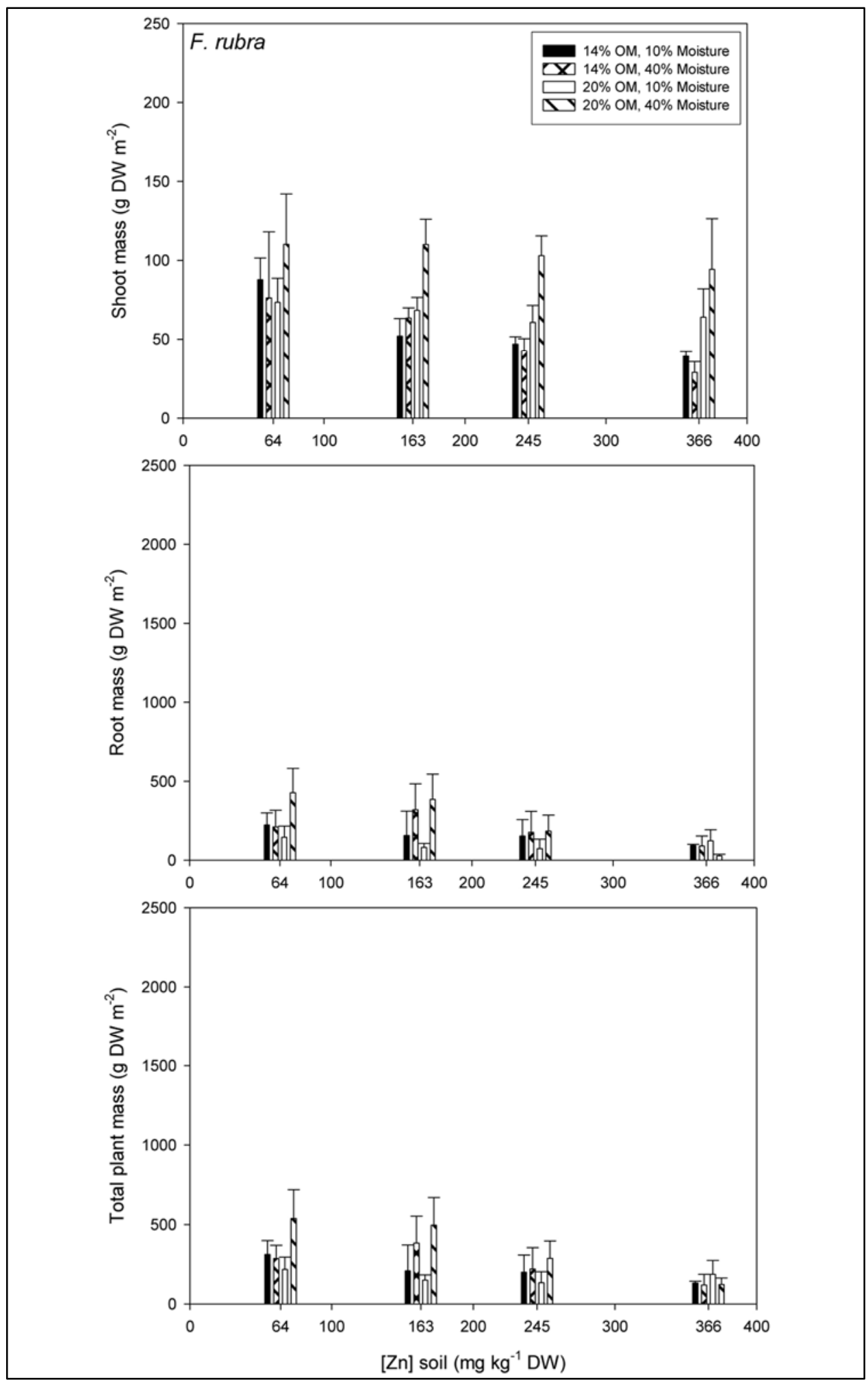

Figure 6. Shoot, root, and total plant mass produced by F. rubra in 49 days in relation to soil zinc concentration. Mean values and standard deviations $(\mathrm{N}=4)$ 


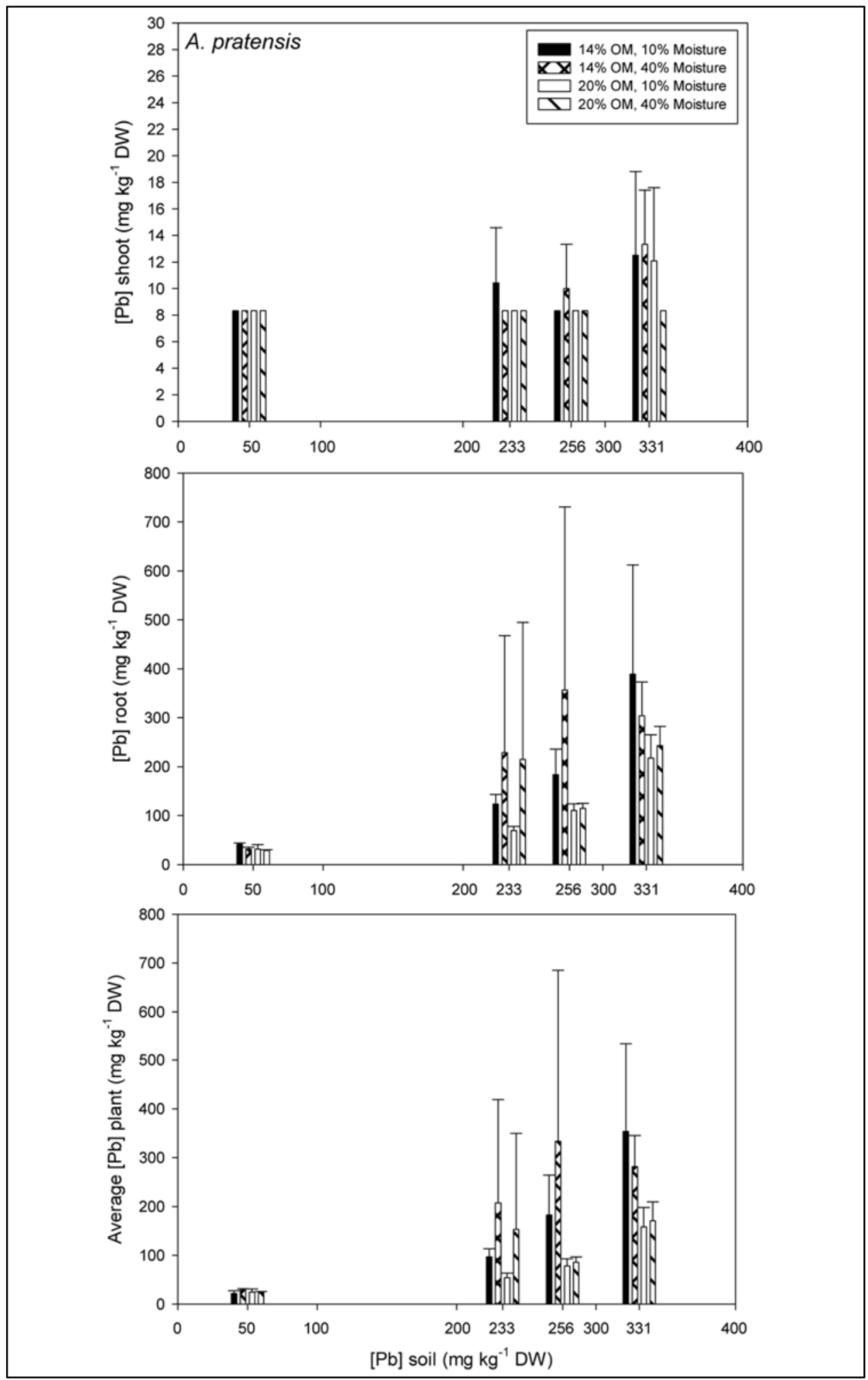

Figure 7. Tissue lead concentrations in shoot, root, and whole plant mass of A. pratensis in relation to soil lead concentration, accumulated in 49 days. Mean values and standard deviations $(\mathrm{N}=4)$ 


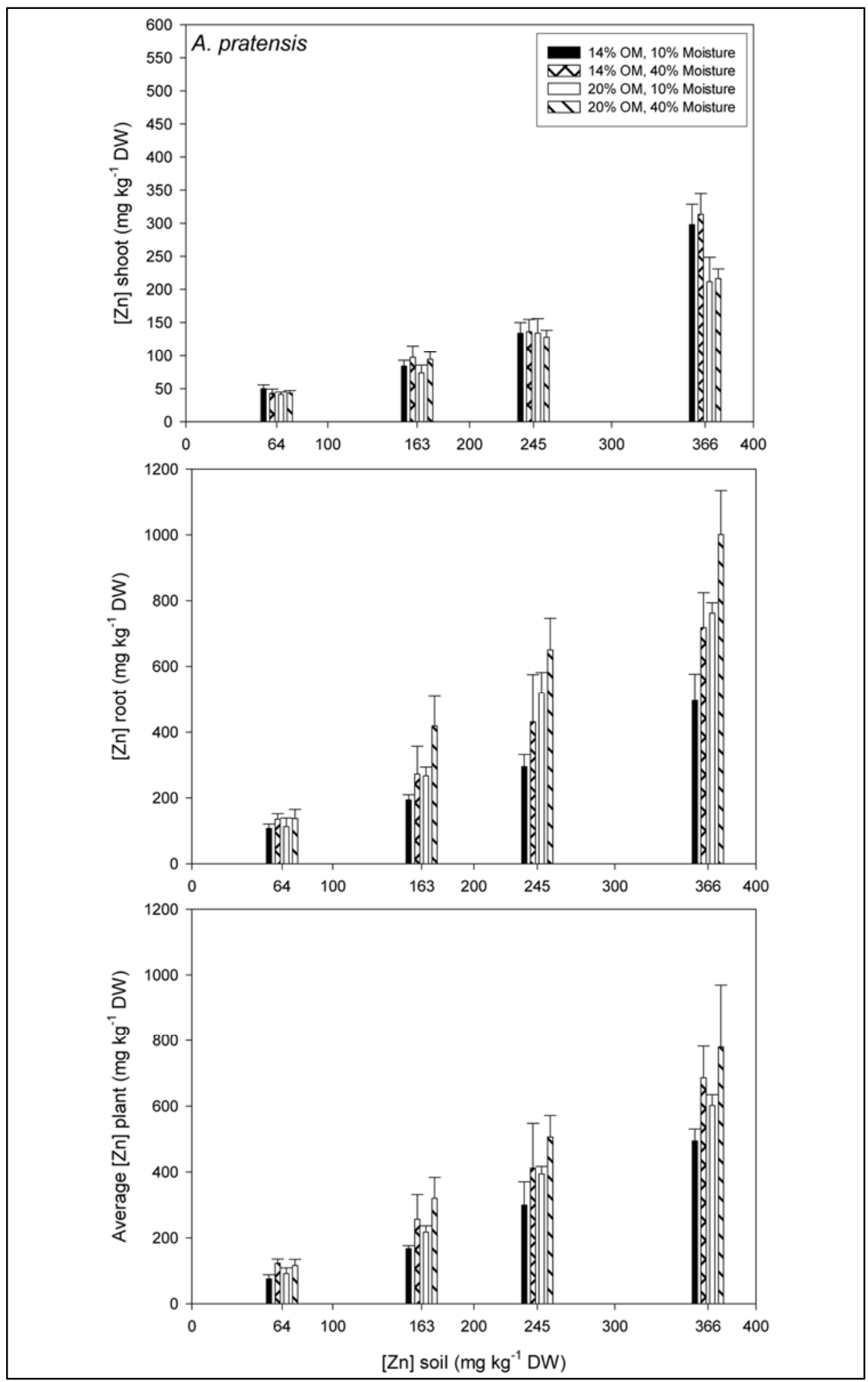

Figure 8. Tissue zinc concentrations in shoot, root, and whole plant mass of A. pratensis in relation to soil zinc concentration, accumulated in 49 days. Mean values and standard deviations $(\mathrm{N}=4)$ 


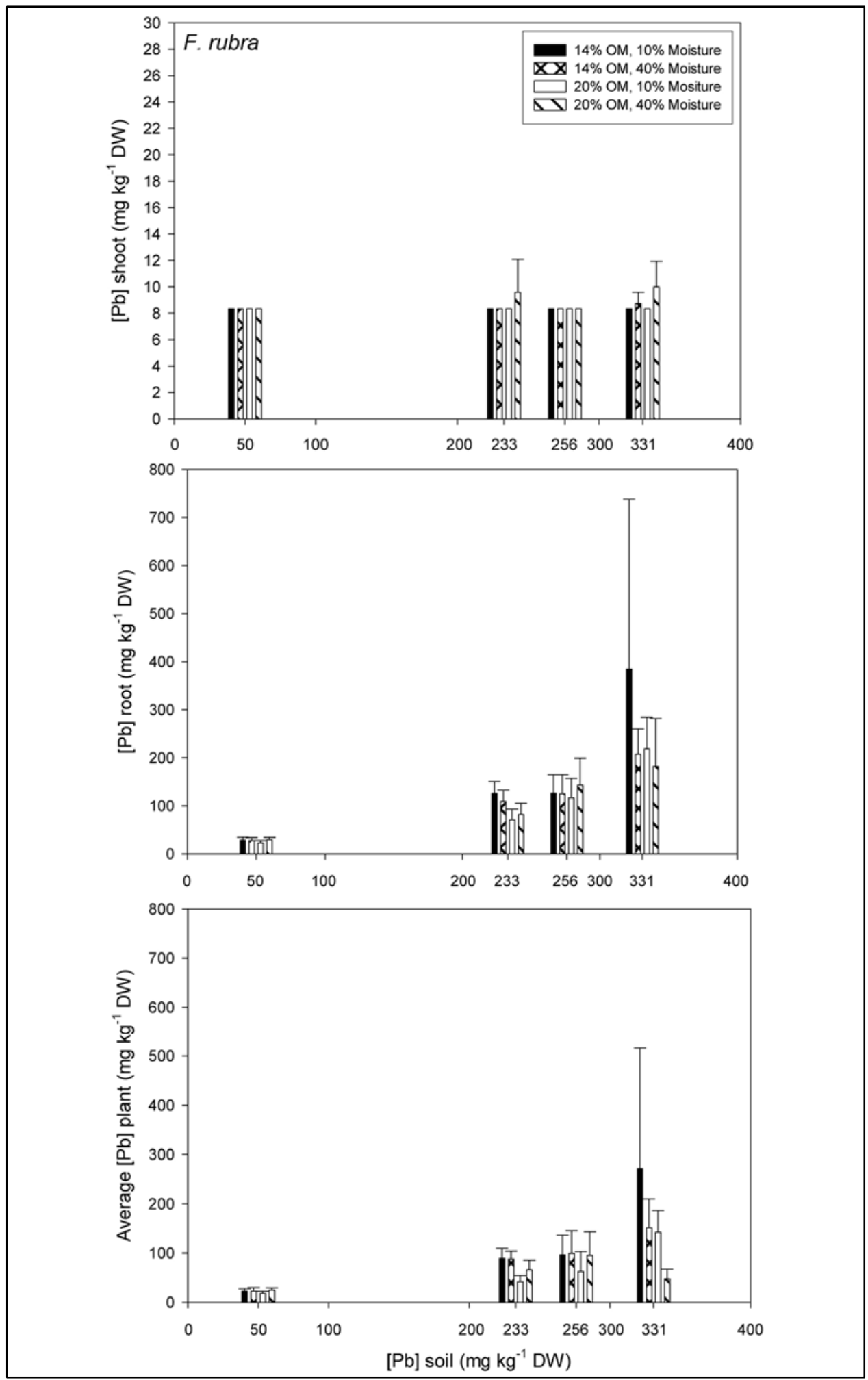

Figure 9. Tissue lead concentrations in shoot, root, and whole plant mass of $F$. rubra in relation to soil lead concentration, accumulated in 49 days. Mean values and standard deviations $(\mathrm{N}=4)$ 


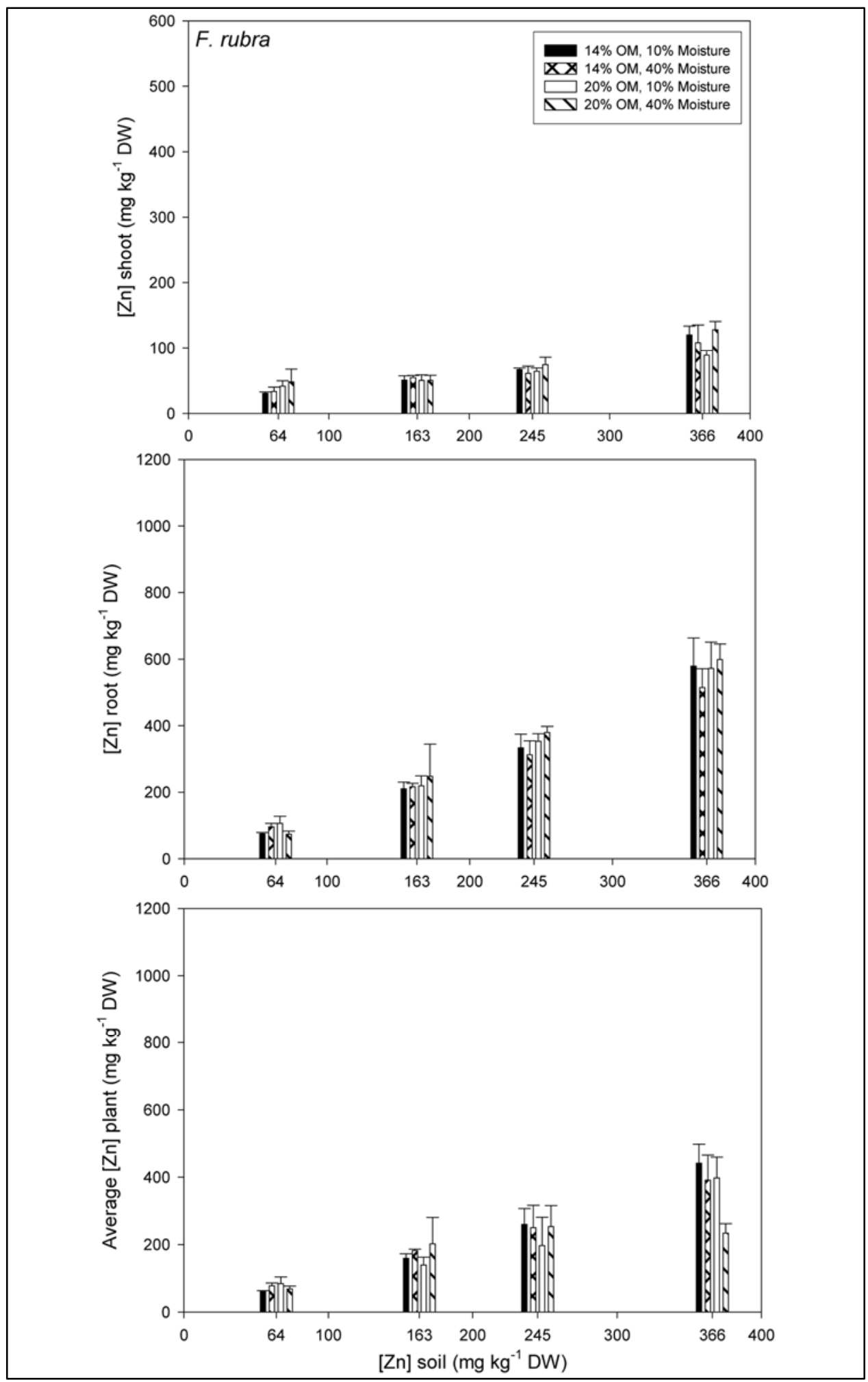

Figure 10. Tissue zinc concentrations in shoot, root, and whole plant mass of $F$. rubra in relation to soil zinc concentration, accumulated in 49 days. Mean values and standard deviations $(\mathrm{N}=4)$ 
Fe was recovered in all shoots and roots, while Ni was recovered only at very low levels in the roots of few plants. As for plant biomass, ANOVA indicated significant effects of almost all main factors and of most of the interactions between the main factors on the tissue metal concentrations of $\mathrm{Pb}$, in roots only, and $\mathrm{Zn}$, in shoots and roots (results not shown). No effects on the tissue-Fe concentrations were noted.

The relationships between plant responses and soil metal concentrations, organic matter and moisture contents were derived using multiple regression. The equations describing the regressions that fit the data are presented in Tables 11 and 12. It was conspicuous that in both plant species shoot-, root biomass, and tissue $\mathrm{Pb}$ concentration were not significantly related to soil $\mathrm{Pb}$ concentration. This is concluded from the fact that (1) shoot and root biomass depended far more strongly on other soil characteristics than on soil $\mathrm{Pb}$ concentration (the constant for $[\mathrm{s}-\mathrm{Pb}]$ in the regression was 0 ), and (2) tissue- $\mathrm{Pb}$ in shoots and roots was not significantly related to soil $\mathrm{Pb}$ concentration $\left(\mathrm{R}^{2}<0.50\right)$. No meaningful relationship between shoot- $\mathrm{Pb}$ and treatment was found in either plant species, because $\mathrm{Pb}$-levels were below detection in most shoot samples. Soil $\mathrm{Pb}$ concentration only significantly contributed to the equation predicting the tissue- $\mathrm{Zn}$ concentration in the roots of both plant species (Tables 11 and 12). Shoot biomass of both plant species depended largely on soil $\mathrm{Zn}$ concentration, root biomass of A. pratensis on soil organic matter and moisture contents, and root biomass of $F$. rubra on soil $\mathrm{Zn}$ concentration and moisture content. Shoot biomass of $A$. pratensis could be predicted from soil $\mathrm{Zn}$ concentration, organic matter, and moisture contents (Table 11). Root tissue-Zn concentration could be predicted from the soil $\mathrm{Pb}$ and $\mathrm{Zn}$ concentrations, and organic matter and moisture contents (Table 11). Shoot tissue-Zn concentration appeared to be predictable from the soil $\mathrm{Pb}$ concentration and organic matter content $\left(\mathrm{R}^{2} 0.93\right)$, but this relationship was not considered as very dependable because the standard error of the equation constant exceeded the value of the constant itself. The variance explained in all other regression equations was too low to be considered as meaningful (i.e., $<0.50$, Table 11). Shoot biomass of F. rubra appeared to be predictable from the $\mathrm{Pb}$ concentration and organic matter and moisture contents of the soil $\left(\mathrm{R}^{2} 0.52\right)$, but this relationship was not considered as very dependable because the standard error of the equation constant exceeded the value of the constant itself (Table 12). Shoot tissue-Zn concentration could be predicted from soil $\mathrm{Zn}$ - concentration, and the root tissue- $\mathrm{Zn}$ concentration from the soil $\mathrm{Pb}$ - and $\mathrm{Zn}$ - concentrations. The variance explained in all other regression equations was too low to be considered as meaningful (i.e., $<0.50$ ).

Several examples are presented in which the regression equations can be used. These equations can not be used to calculate plant biomass and/or tissue- $\mathrm{Pb}$ concentrations in relation to soil $\mathrm{Pb}$ concentrations, because either the soil $\mathrm{Pb}$ concentration did not contribute significantly to the regression relating plant response to soil characteristics, or the regression failed to explain $\geq 50$ percent of the variability in the dataset (Tables 11 and 12). However, the equations can be used for calculations relating plant characteristics to the other relevant soil-based metal, i.e., Zn. 


\begin{tabular}{|c|c|c|c|c|c|}
\hline \multirow{4}{*}{\begin{tabular}{|l|} 
Table 11 \\
Results of $\mathbf{N}$ \\
Variables W \\
$\begin{array}{l}\text { Plant response } \\
\text { parameter }\end{array}$ \\
\end{tabular}} & $\begin{array}{l}\text { e Regression } \\
\text { ant Response }\end{array}$ & $\begin{array}{l}\text { Analyses on } \\
\text { of A. praten }\end{array}$ & $\begin{array}{l}\text { Soil Ch } \\
\text { sis* }\end{array}$ & acterist & \\
\hline & \multirow[b]{3}{*}{ Estimated value } & \multicolumn{4}{|c|}{ Statistic } \\
\hline & & \multicolumn{2}{|c|}{ Parameter } & \multicolumn{2}{|c|}{ Fitted model } \\
\hline & & Standard error & p-value & $p$-value & $\mathbf{R}^{2}$ \\
\hline \multicolumn{4}{|c|}{ Shoot biomass $\left(\mathrm{g} \mathrm{DW} \mathrm{m}^{-2}\right.$ ) } & $<0.001$ & 0.72 \\
\hline a & -28.182 & 19.124 & 0.146 & & \\
\hline $\mathrm{b}$ & 0 & & & & \\
\hline c & -0.191 & 0.026 & $<0.001$ & & \\
\hline $\mathrm{d}$ & 8.421 & 0.999 & $<0.001$ & & \\
\hline $\mathrm{e}$ & 0.854 & 0.199 & $<0.001$ & & \\
\hline \multicolumn{4}{|c|}{ Root biomass $\left(\mathrm{g} \mathrm{DW} \mathrm{m}^{-2}\right)$} & $<0.001$ & 0.32 \\
\hline $\mathrm{a}$ & 666.044 & 250.709 & 0.010 & & \\
\hline $\mathrm{b}$ & 0 & & & & \\
\hline $\mathrm{c}$ & 0 & & & & \\
\hline $\mathrm{d}$ & -32.138 & 13.950 & 0.025 & & \\
\hline $\mathrm{e}$ & 13.251 & 2.790 & $<0.001$ & & \\
\hline \multicolumn{4}{|c|}{ [Tissue-Pb] shoot $\left(\mathrm{mg} \mathrm{kg}^{-1} \mathrm{DW}\right)$} & $<0.001$ & 0.18 \\
\hline$a$ & 7.136 & 0.688 & $<0.001$ & & \\
\hline $\mathrm{b}$ & 0 & & & & \\
\hline $\mathrm{c}$ & 0.011 & 0.003 & $<0.001$ & & \\
\hline $\mathrm{d}$ & 0 & & & & \\
\hline $\mathrm{e}$ & 0 & & & & \\
\hline \multicolumn{4}{|c|}{ [Tissue- $\mathrm{Pb}]$ root $\left(\mathrm{mg} \mathrm{kg}^{-1} \mathrm{DW}\right)$} & $<0.001$ & 0.28 \\
\hline $\mathrm{a}$ & 3.118 & 37.932 & 0.935 & & \\
\hline $\mathrm{b}$ & 0 & & & & \\
\hline $\mathrm{c}$ & 0.788 & 0.159 & $<0.001$ & & \\
\hline $\mathrm{d}$ & 0 & & & & \\
\hline $\mathrm{e}$ & 0 & & & & \\
\hline \multicolumn{4}{|c|}{ [Tissue-Zn] shoot $\left(\mathrm{mg} \mathrm{kg}^{-1} \mathrm{DW}\right)$} & $<0.001$ & 0.93 \\
\hline $\mathrm{a}$ & -5.671 & 6.669 & 0.398 & & \\
\hline $\mathrm{b}$ & -0.248 & 0.058 & $<0.001$ & & \\
\hline $\mathrm{c}$ & 0.910 & 0.053 & $<0.001$ & & \\
\hline $\mathrm{d}$ & 0 & & & & \\
\hline $\mathrm{e}$ & 0 & & & & \\
\hline \multicolumn{4}{|c|}{ [Tissue- $\mathrm{Zn}]$ root $\left(\mathrm{mg} \mathrm{kg}^{-1} \mathrm{DW}\right)$} & $<0.001$ & 0.81 \\
\hline $\mathrm{a}$ & -532.708 & 101.287 & $<0.001$ & & \\
\hline $\mathrm{b}$ & 0.914 & 0.340 & 0.009 & & \\
\hline c & 1.131 & 0.310 & $<0.001$ & & \\
\hline $\mathrm{d}$ & 23.477 & 5.718 & $<0.001$ & & \\
\hline $\mathrm{e}$ & 4.214 & 1.006 & $<0.001$ & & \\
\hline \multicolumn{6}{|c|}{$\begin{array}{l}\text { Note: Models were chosen through stepwise selection with variables remaining in the model if } \\
\text { significant at } p \leq 0.05 \text {. } \\
\text { *In the equation } Y=a+b[s-P b]+c[s-Z n]+d[s-O M]+e[s-m o i s t u r e], Y \text { is the plant response, and } \\
\text { [s-Pb], [s-Zn] are the soil lead and zinc concentrations (in mg } \mathrm{kg}^{-1} \mathrm{DW} \text { ), [s-OM] is the soil organic } \\
\text { matter content (in \%DW), and [s-moisture] the soil moisture content (in \%DW). }\end{array}$} \\
\hline
\end{tabular}




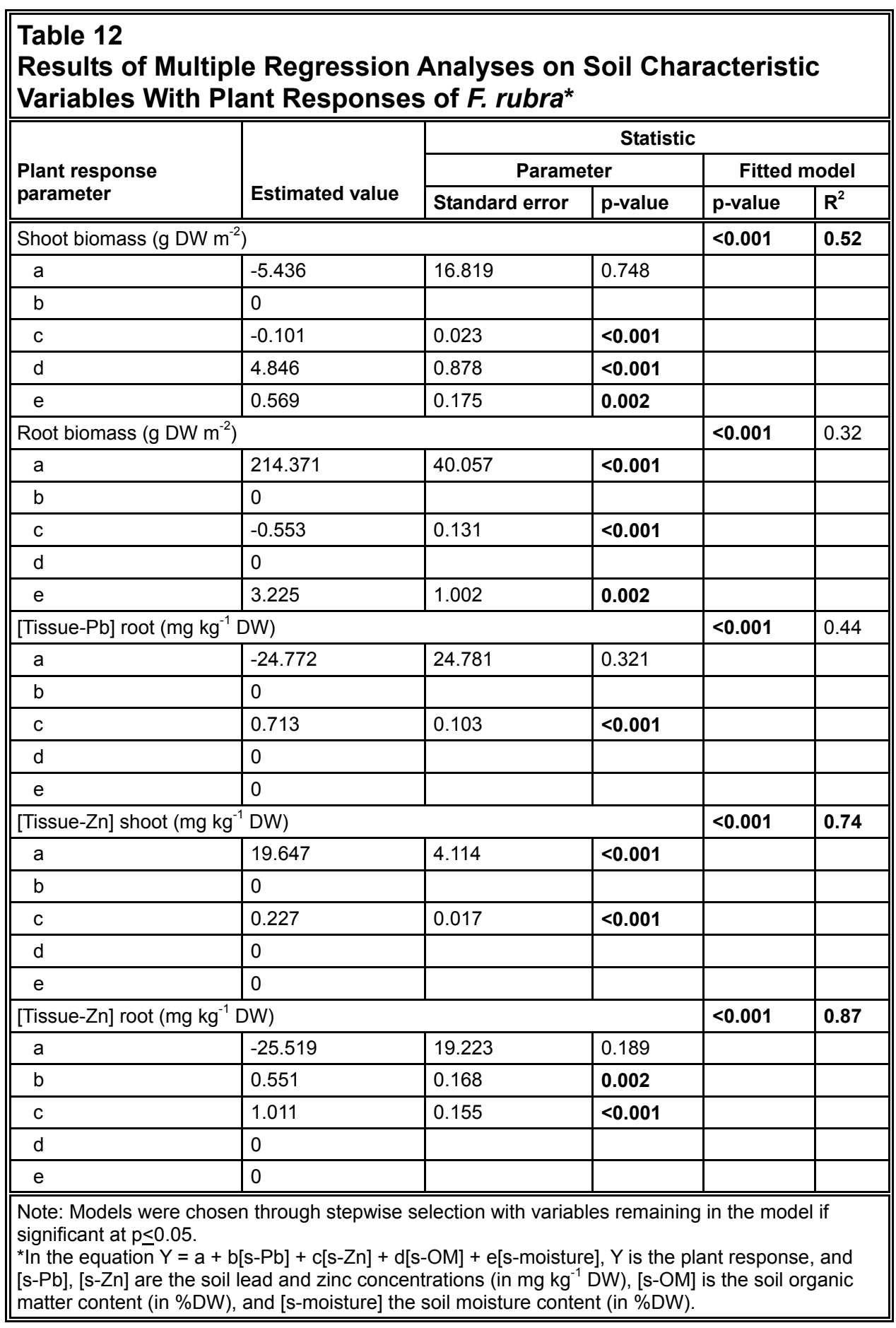

To calculate shoot mass in relation to changes in the soil characteristics, the shoot mass value for $\mathrm{Y}$ is found by substituting relevant numbers in the equation describing the relationship between shoot mass and the relevant soil characteristics. For this calculation, background levels for $\mathrm{Pb}$ and $\mathrm{Zn}$ of, respectively, 71 and $99 \mathrm{mg} \mathrm{kg}^{-1} \mathrm{DW}$ (Table 1), an organic matter content of 20 percent and a soil moisture content of 40 percent were assumed (as used in the plant tests). Examples illustrating the effects of changes in the total-Zn concentrations in the soil 
from mixture background level up to the highest soil metal concentrations are presented in Table 13.

\begin{tabular}{|c|c|c|c|c|c|c|c|}
\hline \multirow{2}{*}{\multicolumn{2}{|c|}{\begin{tabular}{||l} 
Table 13 \\
Plant Respons \\
Metal Concent \\
the Multiple R \\
$\begin{array}{c}{[\text { Total metal] soil }} \\
\left.\text { (mg kg }{ }^{-1} \mathrm{DW}\right)\end{array}$ \\
\end{tabular}}} & $\begin{array}{l}\text { ses in Tern } \\
\text { trations an } \\
\text { egression }\end{array}$ & $\begin{array}{l}\text { Shoot } \\
\text { ota to S } \\
\text { ations* }\end{array}$ & $\begin{array}{l}\text { Root Bior } \\
\text { Accumulat }\end{array}$ & $\begin{array}{l}\text { and Th } \\
\text { actors }\end{array}$ & $\begin{array}{l}\text { r Associat } \\
\text { AF), Calcu }\end{array}$ & $\begin{array}{l}\text { issue- } \\
\text { Using }\end{array}$ \\
\hline & & \multicolumn{6}{|c|}{ Plant response } \\
\hline \multirow[b]{2}{*}{$\mathrm{Pb}$} & \multirow[b]{2}{*}{ Zn } & \multicolumn{2}{|c|}{\begin{tabular}{|c|} 
Biomass $\left(\mathrm{g} \mathrm{DW} \mathrm{m}^{-2}\right)$ \\
\end{tabular}} & \multicolumn{2}{|c|}{ [Tissue metal] $\left(\mathrm{mg} \mathrm{kg}^{-1} \mathrm{DW}\right)$} & \multicolumn{2}{|c|}{ BAF } \\
\hline & & A. pratensis & F. rubra & A. pratensis & F. rubra & A. pratensis & F. rubra \\
\hline \multicolumn{8}{|c|}{ Lead } \\
\hline & & Shoots & Shoots & & & & \\
\hline \multirow[t]{2}{*}{$71-346$} & 99 & \begin{tabular}{|l|}
87.2 \\
\end{tabular} & 104.2 & $\leq 8.33$ & $\leq 8.33$ & NA & NA \\
\hline & & Roots & Roots & & & & \\
\hline $71-346$ & 99 & $320-488^{a}$ & $83-251^{\mathrm{a}}$ & 81.13 & 181.0 & NA & NA \\
\hline \multicolumn{8}{|c|}{ Zinc } \\
\hline & & Shoots & Shoots & & & & \\
\hline 71 & 99 & 87.2 & 104.2 & 66.8 & 42.1 & 0.67 & 0.43 \\
\hline 71 & 327 & 43.6 & & 274.3 & & 3.89 & \\
\hline 71 & 615 & & 52.1 & & 161.0 & & 2.27 \\
\hline \multirow[t]{2}{*}{346} & 307 & 47.4 & 83.2 & 187.9 & 65.9 & 0.56 & 0.19 \\
\hline & & Roots & Roots & & & & \\
\hline 71 & 99 & $488^{a}$ & $251^{a}$ & 282.3 & 267.4 & 2.85 & 2.70 \\
\hline 346 & 307 & $320^{a}$ & $83^{\mathrm{a}}$ & 768.9 & 249.0 & 2.50 & 0.81 \\
\hline
\end{tabular}

Results of these calculations indicate the following. Shoot biomass of A. pratensis would decrease by 50 percent at a soil $\mathrm{Zn}$ concentration increasing from 99 to $327 \mathrm{mg} \mathrm{kg}^{-1} \mathrm{DW}$, concomitant with a tissue- $\mathrm{Zn}$ concentration increasing from 67 to $274 \mathrm{mg} \mathrm{kg}^{-1} \mathrm{DW}$, and a Biota to Soil Accumulation Factor (BAF) increasing from 0.67 to 3.89. In F. rubra shoot biomass would decrease by 50 percent at a soil-Zn concentration increasing from 99 to $615 \mathrm{mg} \mathrm{kg}^{-1}$ soil DW, concomitant with a tissue-Zn concentration increasing from 42 to $161 \mathrm{mg}$ $\mathrm{kg}^{-1} \mathrm{DW}$, and a BAF increasing from 0.43 to 2.27 .

The regressions were also used to calculate the expected plant biomass and tissue-Zn concentrations at soil-metal concentrations surrounding the LBP-contaminated buildings at Fort Lewis, i.e., $346 \mathrm{mg} \mathrm{Pb} \mathrm{kg}^{-1}$ and $307 \mathrm{mg} \mathrm{Zn} \mathrm{kg}^{-1}$ soil DW (Table 13). In this area the following biomass and tissue- $\mathrm{Zn}$ levels can be expected: A. pratensis: biomass, shoots 47 and roots $320 \mathrm{~g} \mathrm{DW} \mathrm{m}^{-2}$; tissue- $\mathrm{Zn}$, shoots 188 and roots $769 \mathrm{mg} \mathrm{kg}^{-1}$ DW. F. rubra: biomass, shoots 83 and roots $83 \mathrm{~g} \mathrm{DW} \mathrm{m}^{-2}$; tissue-Zn, shoots 66 and roots $249 \mathrm{mg} \mathrm{kg}^{-1} \mathrm{DW}$. Comparison of the calculated results with the measured values (Tables 8 and 10) indicates that the regressions (1) underestimate $A$. pratensis shoot biomass, and are similar to the measured values for tissue-Zn levels in shoots and roots; and (2) overestimate F. rubra shoot biomass, are similar to the measured values for shoot tissue- $\mathrm{Zn}$ level, overestimate root tissue- $\mathrm{Zn}$ levels at background soil- $\mathrm{Pb}$ and $-\mathrm{Zn}$ concentrations and are similar to measured values for root tissue- $Z n$ levels at high soil$\mathrm{Pb}$ and $-\mathrm{Zn}$ levels. 
Frequently used measures to describe toxicity are the lethal concentration (LC), i.e., the concentration of a toxin that kills a specified percentage of the organism; the effective concentration (EC), i.e., the concentration of a toxin that produces an observable negative effect in the organism; and the phytotoxicity threshold (PT), i.e., the tissue concentration of a plant that corresponds with a defined growth reduction (ASTM 1998, Ross and Kaye 1994). The effective concentrations that reduced plant biomass by 50 percent in 49 days (49d-EC50) were calculated using the regression equations (see above). The 49d-EC50 for $\mathrm{Pb}$ could not be determined in this study, because $\mathrm{Pb}$ levels in the shoots were below the detection level of $8.33 \mathrm{mg} \mathrm{kg}^{-1} \mathrm{DW}$ in most samples. EC50s for $\mathrm{Zn}$ in shoots were calculated using this approach, and were $327 \mathrm{mg} \mathrm{Zn} \mathrm{kg}^{-1} \mathrm{DW}$ for A. pratensis and $615 \mathrm{mg} \mathrm{Zn} \mathrm{kg}^{-1} \mathrm{DW}$ for $F$. rubra (Table 14). These EC50s are in the same range as published for another grass species, Lolium perenne, and for two cereals (Boawn and Rasmussen 1971, Davis and Beckett 1978), but far lower than recently determined in grass species used for reclamation purposes (Paschke et al. 2000).

\begin{tabular}{|c|c|c|c|c|c|}
\hline \multicolumn{6}{|c|}{$\begin{array}{l}\text { Table } 14 \\
\text { Commonly Cited Deficient, Normal, and Phytotoxic Metal } \\
\text { Concentrations in Mature Plant Shoot Tissues (mg kg }{ }^{-1} \text { DW) }\end{array}$} \\
\hline Element & Species & Deficient & Normal & Phytotoxic & Reference \\
\hline \multirow[t]{3}{*}{ Lead } & & Not essential & $0.5-5$ & & Reeves et al. 1995 \\
\hline & & & $2-5$ & & Chaney 1983 \\
\hline & & & $5-10$ & $30-300$ & $\begin{array}{l}\text { Kabata-Pendias and } \\
\text { Pendias } 1992\end{array}$ \\
\hline \multirow[t]{19}{*}{ Zinc } & & $<10-20$ & & & $\begin{array}{l}\text { Kabata-Pendias and } \\
\text { Pendias } 1992\end{array}$ \\
\hline & & & $15-150$ & $500-1500$ & Chaney 1983 \\
\hline & & $<15$ & & & Reeves et al. 1995 \\
\hline & & & $27-150$ & $100-400$ & $\begin{array}{l}\text { Kabata-Pendias and } \\
\text { Pendias } 1992\end{array}$ \\
\hline & & $<20$ & & $>400$ & Tisdale et al. 1985 \\
\hline & & & $10-100$ & & Reeves et al. 1995 \\
\hline & & & 70 & & Brooks 1983 \\
\hline & & $<15-20$ & & $100->300$ & Marschner 1997 \\
\hline & & & $25-150$ & & Tisdale et al. 1985 \\
\hline & Elymus trachycaulus & & & $5026^{\mathrm{a}}$ & Paschke et al. 2000 \\
\hline & Deschampsia caespitosa & & & $4380^{a}$ & Paschke et al. 2000 \\
\hline & Leymus cinereus & & & $2562^{a}$ & Paschke et al. 2000 \\
\hline & Poa ample & & & $2449^{a}$ & Paschke et al. 2000 \\
\hline & Lolium perenne & & & $210^{a}$ & $\begin{array}{l}\text { Davis and Beckett } \\
1978\end{array}$ \\
\hline & Triticum vulgare & & & $560^{b}$ & $\begin{array}{l}\text { Boawn and } \\
\text { Rasmussen } 1971 \\
\end{array}$ \\
\hline & Hordeum vulgare & & & $540^{b}$ & \begin{tabular}{|l|} 
Boawn and \\
Rasmussen 1971 \\
\end{tabular} \\
\hline & Cynodon dactylon & & 163 & $324^{\mathrm{a}}$ & Best et al. 2003 \\
\hline & Alopecurus pratense & & & $327^{a}$ & Best et al., this study \\
\hline & Festuca rubra & & & $615^{a}$ & Best et al., this study \\
\hline
\end{tabular}




\section{Discussion and Conclusions}

\section{Phytoextraction or Phytostabilization}

Of both grass species included in the current study, Alopecurus pratensis produced about twice as much plant biomass as Festuca rubra in 49 days, i.e., 546 versus $249 \mathrm{~g} \mathrm{DW} \mathrm{m}^{-2}$. Both species allocated most of their biomass below ground. Both plant species exhibited the tendency to accumulate $\mathrm{Pb}$ solely below ground without upward transport, and to accumulate $\mathrm{Zn}$ largely below ground with limited upward transport. The latter characteristic is typical for plant species used in phytostabilization strategies. A. pratensis was the better metal accumulator of both grasses: it accumulated $\mathrm{Pb}$ and $\mathrm{Zn}$ to a higher extent than F. rubra. A. pratensis was also the species that allocated a relatively higher proportion of its biomass in roots than F. rubra, making the former relatively more suitable for use in phytostabilization than the latter. However, A. pratensis proved to be more sensitive to $\mathrm{Zn}$ than $F$. rubra, with the effective concentrations that reduced plant biomass by 50 percent in 49 days (49d-EC50) being $327 \mathrm{mg} \mathrm{Zn} \mathrm{kg} \mathrm{DW}^{-1}$ for A. pratensis and $615 \mathrm{mg} \mathrm{Zn} \mathrm{kg}^{-1} \mathrm{DW}$ for F. rubra. The latter characteristic makes A. pratensis less suitable to use in areas with high $\mathrm{Zn}$ contamination levels.

\section{Effects of the Vegetation on the Leachability of the Soil}

Both plant species increased the leachable soil metal fractions from below detection to $0.15 \mathrm{~kg} \mathrm{~Pb} \mathrm{ha}^{-1}$, and from 0.48 to $2.00 \mathrm{~kg} \mathrm{Zn} \mathrm{ha}^{-1}$. The total leachable quantities, however, were very low.

\section{Effects of Soil Characteristics on the Vegetation Responses}

It was conspicuous that $\mathrm{Pb}$ accumulated to a lesser extent than $\mathrm{Zn}$ in the plants, despite the fact that both metals were present at similar concentrations in the soil mixtures and both metals have similar CSCL levels. This may be explained by the fact that $\mathrm{Pb}$ was less bioavailable than $\mathrm{Zn}$, probably because $\mathrm{Pb}$ in the soil was largely in the form of paint crystals. 
Increasing soil $\mathrm{Pb}$ levels concomitant with increasing $\mathrm{Zn}$ levels significantly reduced the shoot and root biomass, increased the tissue $\mathrm{Zn}$ concentrations in shoots, and increased the $\mathrm{Pb}$ and $\mathrm{Zn}$ concentrations in the roots of both plant species. Increasing soil organic matter and moisture contents both stimulated the production of shoot and root biomass, with the only exception that increasing organic matter content decreased root biomass in A. pratensis. Although the effects of the main treatment factors (soil metal concentrations, organic matter, and moisture contents) on plant biomass and tissue $\mathrm{Pb}$ and $\mathrm{Zn}$ concentrations (except for the $\mathrm{Pb}$ levels in shoots) were significant, the effects of most interactions were significant also. The latter phenomenon obscured the relative impacts of main factors and interactions.

\section{Potential Importance of Phytoremediation Using the Tested Grass Species for Remediation of Lead-Based-Paint Contamination at Fort Lewis, WA}

The lead-based-paint contamination at Fort Lewis in the area between C Street and D Street was moderately high (310-395 $\left.\mathrm{mg} \mathrm{Pb} \mathrm{kg}^{-1} \mathrm{DW}\right)$ in the soil adjacent to several buildings, high close to the chapel $\left(3,360 \mathrm{mg} \mathrm{Pb} \mathrm{kg}^{-1} \mathrm{DW}\right)$ while site-background levels were in the order of $70 \mathrm{mg} \mathrm{Pb} \mathrm{kg}^{-1} \mathrm{DW}$. It was concluded that, based on their biogeographical distribution and their metal tolerance characteristics, both grass species evaluated in the current tests would be able to persist in the area with moderate metal contamination, but would not survive at high metal contamination.

To evaluate the impact of vegetation on the total soil metal contamination, total soil metals quantities contained in the upper $33 \mathrm{~cm}$, their mobilities, metal leachability from bare and vegetated soil, and metal quantities contained in plant material were quantified (Table 15). For this, evaluation data on plant biomass and tissue metal concentrations from Table 13, and leachable soil metal concentrations from Table 7 were used. The metals contained in the plant mass represented maximally 2.2 percent of the total metals presumed to be present on site ( $\mathrm{Zn}$ in A. pratensis only). Of the total metals contained in the plant mass, only a very small fraction was above ground and, therefore, harvestable by mowing and subsequent export, leaving the perennial vegetation intact. Although the grass species chosen could be mown up to four times per year, the yield would still be low, and metal removal using this method would be consequently low also. Presence of the vegetation increased the leachability of the soil considerably. However, its impact was minimal because the leachable metal fractions were extremely low compared to the total soil metal levels, i.e., in the order of 00.3 percent. Thus, in the Fort Lewis case the importance of the presence of a grass vegetation at the LBP-contaminated site would largely lie in serving as a soil cover, preventing metals from being released from the site as parts of dust particles or dissolved within surface runoff. In case the area between $\mathrm{C}$ Street and D Street is planned to be used as a housing area, an effective approach would be to remove the $7.5-\mathrm{cm}$ top layer of the soil that contains most of the easily visible 
paint chips, or amend the soil with phosphate rocks, and establish a vegetative cover composed by the tested grass species between the houses.

\begin{tabular}{|c|c|c|}
\hline \multicolumn{3}{|c|}{$\begin{array}{l}\text { Table } 15 \\
\text { Estimates of Lead and Zinc Quantities Present in the Upper 33-cm } \\
\text { Soil Surface Layer in the Metals-Contaminated Area of Fort Lewis, } \\
\text { Their Leachable Fractions, and 49-day Accumulation in } \\
\text { A. pratensis and F. rubra Vegetation }\end{array}$} \\
\hline Compartment & Lead $\left(\mathrm{kg} \mathrm{ha}^{-1}\right)$ & Zinc $\left(\mathrm{kg} \mathrm{ha}^{-1}\right)$ \\
\hline \multicolumn{3}{|c|}{ Fort Lewis Building B Soil } \\
\hline Total & 127.3 & 113.0 \\
\hline Leachable, bare & 0 & 0.48 \\
\hline Leachable, vegetated & 0.15 & 2.00 \\
\hline \multicolumn{3}{|c|}{ Vegetation } \\
\hline A.pratensis shoot biomass & 0.007 & 0.089 \\
\hline A. pratensis total biomass & 0.266 & 2.551 \\
\hline F. rubra shoot biomass & 0.001 & 0.001 \\
\hline F. rubra total biomass & 0.151 & 0.481 \\
\hline
\end{tabular}

The results of the current study are in agreement with an ongoing field experiment in Canada where no decrease in total $\mathrm{Pb}$ concentration in the soil was found during phytoremediation treatment in a period up to three years (Foye et al. 2001). We believe that the main reasons for far higher estimates of amounts of metals removed by harvesting herbaceous vegetation are that biomass production data of fertilized and watered crops, such as corn, are used for the estimates, without taking growth inhibition by metal toxicity, low site fertility, and suboptimal soil moisture into account. Furthermore, often accumulation data of either hyperaccumulators or plants exposed to only one metal species are used, whereas in reality usually more than one metal is present at sites that are to be remediated, leading to different tissue metal concentrations.

\section{Conclusions}

1. Phytostabilization appears to be a strategy that would considerably reduce ecological risk potentially posed by LBP-contaminated soils at Fort Lewis.

2. The grass vegetation would concentrate most of the mobile $\mathrm{Pb}$ fraction of the LBP in its root zone, because upward transport of $\mathrm{Pb}$ in the vegetation is negligeable and most paint chips reside in the upper $7.5-\mathrm{cm}$ soil layer where grass roots can reach them.

3. The grass vegetation would prevent metals from off-site release as parts of dust particles or dissolved within surface runoff. 
4. For soil contaminated by $\mathrm{Pb}$ alone, A. pratensis would be the most suitable grass species to use, since it has a high tolerance for $\mathrm{Pb}$ and stores relatively more biomass and the $\mathrm{Pb}$ contained herein below ground.

5. For soil contaminated by both $\mathrm{Pb}$ and $\mathrm{Zn}, F$. rubra would be the most suitable grass species to use, since it has a high tolerance for both $\mathrm{Pb}$ and $\mathrm{Zn}$.

6. Regular mowing and mulching would be a viable management option, which would not spread bioavailable $\mathrm{Pb}$ around and leave the vegetation intact.

7. Potentially lower bioavailability and solubility of the LBP-related $\mathrm{Pb}$ in the soil may be attained by (a) removal of the upper $7.5 \mathrm{~cm}$ of the soil, or (b) soil amendment with phosphate rocks. 


\section{References}

Acar, Y. B., and Alshawabkwe, A. N. (1993). "Principles of electrokinetic remediation," Environmental Science \& Technology 27, 2638-2647.

Allen, S. E., Grimshaw, H. M., Parkinson, J. A., and Quarmby, C. (1974). Chemical analysis of ecological materials. S.E. Allen et al. ed., Wiley, New York, 21-22.

Anonymous. (2001). "Post trip report. Site characterization Fort Lewis, WA. Lead-based paint evaluation for phytoremediation.” $23 \mathrm{pp}$.

ASTM. (1998). Standard guide for conducting terrestrial plant toxicity tests. E-1963-98. American Society for Testing and Materials, Philadelphia, PA.

Berti, W. R., and Cunningham, S. D. (1997). "In-place inactivation of $\mathrm{Pb}$ in $\mathrm{Pb}-$ contaminated soils.” Environmental Science and Technology 31: 1359-1364.

Best, E. P. H., and Jacobs, F. H. H. (2001). "Production, nutrient availability, and elemental balances of two meadows affected by different fertilization and water table regimes," Plant Ecology 155, 61-73.

Best, E. P. H., Geter, K. N., and Tatem, H. E. (2003). "Validation of pathway analysis of metals from aged dredged material using plants and worms." Dredging Operations and Environmental Research DOER Technical Note (ERDC TN-DOER-C32), U.S. Army Engineer Research and Development Center, Vicksburg, MS. January 2003.

http://www.wes.army.mil/el/dots/doer/pdf/doerc32.pdf.

Blaylock, M. J., Salt, D. E., Dushenkov, S., Zajharova, O., Gussman, C., et al. (1997). "Enhanced accumulation of Pb in Indian mustard by soil-applied chelating agents," Environmental Science and Technology 31, 860-865.

Boawn, L. C., and Rasmussen, P. E. (1971). "Crop response to excessive zinc fertilization of alkaline soil," Agronomy Journal 63, 874-876.

Bradshaw, A. D., and Chadwick, M. D. (1980). The restoration of land: The geology and reclamation of derelict and degraded land. University of California Press, Berkeley/Los Angeles, CA. 
Brannon, J. M., Myers, T. E., and Tardy, B. A. (1994). "Leachate testing and evaluation from freshwater sediments," Miscellaneous Paper D-94-1, U.S. Army Engineer Waterways Experiment Station, Vicksburg, MS.

Brooks, R. R. (1983). Biological methods of prospecting for minerals. Wiley, New York, 322 p.

Brooks, R. R. (1997). "General introduction.” Plants that hyperaccumulate heavy metals. R.R. Brooks, ed., CAB International, Wallingford, UK, 1-14.

Brooks, R. R., Lee, J., Reeves, R. D., and Jaffre, T. (1977). "Detection of nickeliferous rocks by analysis of herbarium specimens of indicator plants," Journal of Geochemical Exploration 7, 49-57.

Chaney, R. L. (1983). "Potential effects of waste constituents on the food chain," Land treatment of hazardous wastes. J.F. Parr et al., ed., Noyes Data Corporation, Park Ridge, NJ, 152-240.

Chaney, R. L., and Ryan, J. A. (1994). "Risk-based standards for arsenic, lead and cadmium in urban soils." DECHEMA, Frankfurt, 1-130.

Cotter-Howells, J., and Caporn, S. (1996). "Remediation of contaminated land by formation of heavy metal phosphates." Applied Geochemistry 11, 335-342.

Cunningham, S. D., and Ow, D. W. (1996). "Promises and prospects of phytoremediation. Update on Biotechnology," Plant Physiology 110, 715-719.

Cunningham, S. D., Berti, W. R., and Huang, J. W. (1995a). "Phytoremediation of contaminated soils," Trends in Biotechnology 13, 393-397.

Cunningham, S. D., Berti, W. R., and Huang, J. W. (1995b). "Phytoremediation of contaminated soils and sludges by green plants," Bioremediation of inorganics. R.E. Hinchee, J.L. Means, and D.R. Burris, ed., Battelle Press, Columbus, $\mathrm{OH}, 33-54$.

Davis, R. D., and Beckett, P. H. T. (1978). "Upper critical levels of toxic elements in plants. 2. Critical levels of copper in young barley, wheat, rape, lettuce and ryegrass, and of nickel and zinc in young barley and ryegrass," New Phytologist 80, 23-32.

Ebbs, S. D., Lasat, M. M., Brady, D. J., Cornish, J., Gordon, R., and Kochian, L. V. (1997). "Phytoextraction of cadium and zinc from a contaminated soil," Journal of Environmental Quality 26, 1424-1430.

Foye, D., Morse, J., Reimer, K., and Zeeb, B. (2001). "Phytoremediation of leadcontaminated soils at CFB Chilliwack," Society of Environmental Toxicology and Chemistry 22nd Annual Meeting, Baltimore, MD, 11-15 November 2001. 32 . 
Gleason, H. E., and Cronquist, A. (1991). Manual of vascular plants of the northeastern United States and adjacent Canada, Second Edition. The New York Botanical Garden, Bronx, New York 10458, 749, 769.

Hach. (1992). SIW-1 Soil Test Kit Manual. Technical Document downloaded from $h t t p: / / w w w . h a c h . c o m$.

Houba, V. J. G., Van der Lee, J. J., and Novozamsky, I. (1995). "Soil and plant analysis," A series of syllabi. Part 5B: Soil Analysis procedures and other procedures. Determination of potassium. Department of Soil Science and Plant Nutrition, Wageningen Agricultural University, 160-165.

International Organization for Standardization (ISO). (1994). Soil QualityDetermination of $\mathrm{pH}$. ISO 10390. Geneva, Switzerland.

Kabata-Pendias, A., and Pendias, H. (1992). Trace elements in soils and plants, 2nd Ed. CRC Press, Boca Raton, FL.

Leblanc, M., Robinson, B. H., and Brooks, R. R. (1997). Hyperaccumulation de thallium par Iberis intermedia (Brassicacee). Comptes rendus de l'Academie des Sciences, Paris, Serie D.

Levy, D. B., Redente, E. F., and Uphoff, G. D. (1999). "Evaluating the phytotoxicity of $\mathrm{Pb}-\mathrm{Zn}$ tailings to big bluestem (Andropogon Gerardii Vitman) and switchgrass (Panicum virgatum L.)," Soil Science 164, 363-375.

Ma, Q. J., Logan, T. J., and Traina, S. J. (1995). "Lead immobilization from aqueous solutions and contaminated soils using phosphate rocks." Environmental Science and Technology 29, 1118-1126.

Marschner, H. (1997). Mineral nutrition of higher plants, 2nd ed., Academic Press, London.

McGrath, S. P., Shen, Z. G., and Zhao, F. J. (1997). "Heavy metal uptake and chemical changes in the rhizosphere of Thlaspi caerulescens and Thlaspi ochroleucum in contaminated soils," Plant \& Soil 188, 153-159.

MTCA. (2002). State of Washington Model Toxics Control Act (MTCA) regulation (http://www.ecy.wa.gov/biblio/wac173340.html.

Paschke, M. W., Redente, E. F., and Levy, D. B. (2000). "Zinc toxicity thresholds for important reclamation grass species of the western United States," Environmental Toxicology and Chemistry 19, 2751-2756.

Reeves, R. D., Baker, A. J. M., and Brooks, R. R. (1995). “Abnormal accumulation of trace metals by plants," Mining Environmental Management 3, 4-8.

Robinson, B. H., Chiarucci, A., Brooks, R. R., Petit, D., Kirkman, J. H., Gregg, P. E. H., and De Dominicis, V. (1997). "The nickel hyperaccumulator plant Alyssum bertolonii as a potential agent for phytoremediation and phytomining of nickel," Journal of Geochemical Exploration 59, 75-86. 
Ross, S. M., and Kaye, K. J. (1994). "The meaning of metal toxicity in soil-plant systems," Toxic metals in soil-plant systems. S.M. Ross, ed., John Wiley \& Sons, Chicester, UK, 27-61.

Salt, D. E., Smith, R. D., and Raskin, I. (1998). "Phytoremediation," Annual Review of Plant Physiology and Plant Molecular Biology 49, 643-668.

Tisdale, S. L., Nelson, W. L., and Beaton, J. D. (1985). Soil fertility and fertilizers. 4th Ed., Macmillan Publishing Company, New York.

U.S. Environmental Protection Agency. (1994). Test methods for evaluating solid wastes, Physical/chemical methods, Final update III, Method 7471a, SW846, 3rd Ed., Office of Solid Waste and Emergency Response, Washington, DC.

U.S. Environmental Protection Agency. (1996). Test methods for evaluating solid wastes, Physical/chemical methods, Final update III, Method 3050b, SW846, 3rd Ed., Office of Solid Waste and Emergency Response, Washington, DC.

U.S. Environmental Protection Agency, Office of Solid Waste, Washington D.C. (1999). Data collection for the hazardous waste identification rule. Section 14.0 Ecological benchmarks. Center for Environmental Analysis, Research Triangle Institute, 3040 Cornwallis Road, Research Triangle Park, NC 27709-2194, Under Contract No. 68-W-98-085.

Van der Zee, S. E. A. T. M., Fokkink, L. G. J., and Van Riemsdijk, W. H. (1987). "A new technique for assessment of reversibly adsorbed phosphate," Soil Science Society of America Journal 51, 599-604. 


\section{Appendix A Table}

\section{Leachable Metal Fractions and pH of Soil Mixtures After 49-d Incubation With $A$. pratensis and F. rubra. Metals in $\mathrm{mg} \mathrm{kg}^{-1} \mathrm{DW}$; mean values and standard deviations $(\mathrm{N}=3)$}

\begin{tabular}{|c|c|c|c|c|c|c|c|c|}
\hline \multirow[b]{3}{*}{ Characteristic } & \multicolumn{8}{|c|}{ Soil mixture } \\
\hline & \multicolumn{4}{|c|}{$14 \%$ Organic Matter Class $^{a}$} & \multicolumn{4}{|c|}{$20 \%$ Organic Matter Class } \\
\hline & MB-Pb ${ }^{b}$ & $233 \mathrm{~Pb}$ & $256 \mathrm{~Pb}$ & $331 \mathrm{~Pb}$ & MB-Pb & $233 \mathrm{~Pb}$ & $256 \mathrm{~Pb}$ & $331 \mathrm{~Pb}$ \\
\hline \multicolumn{9}{|c|}{ A. pratensis $10 \%$ Moisture Class } \\
\hline BL-Lead & $0.19 \pm 0.00$ & $0.22 \pm 0.04$ & $0.19 \pm 0.02$ & $0.43 \pm 0.07$ & $0.20 \pm 0.00$ & $0.20 \pm 0.01$ & $0.20 \pm 0.00$ & $0.20 \pm 0.01$ \\
\hline BL-Zinc & $0.22 \pm 0.05$ & $0.44 \pm 0.09$ & $0.62 \pm 0.03$ & $1.28 \pm 0.08$ & $0.24 \pm 0.02$ & $1.03 \pm 0.18$ & $1.48 \pm 0.14$ & $2.67 \pm 0.20$ \\
\hline BL-Iron & $1.16 \pm 0.23$ & $3.35 \pm 0.63$ & $2.31 \pm 0.35$ & $3.05 \pm 0.59$ & $0.77 \pm 0.14$ & $0.47 \pm 0.07$ & $0.50 \pm 0.06$ & $0.25 \pm 0.05$ \\
\hline $\mathrm{pH}_{\text {water }}$ & $5.31 \pm 0.10$ & $5.31 \pm 0.05$ & $5.40 \pm 0.01$ & $5.33 \pm 0.07$ & $5.36 \pm 0.02$ & $5.34 \pm 0.02$ & $5.40 \pm 0.01$ & $5.38 \pm 0.03$ \\
\hline \multicolumn{9}{|c|}{ A. pratensis $40 \%$ Moisture Class } \\
\hline BL-Lead & $0.20 \pm 0.01$ & $0.39 \pm 0.07$ & $0.39+0.08$ & $0.37 \pm 0.03$ & $0.21 \pm 0.00$ & $0.21 \pm 0.00$ & $0.20 \pm 0.01$ & $0.21 \pm 0.00$ \\
\hline BL-Zinc & $0.17 \pm 0.01$ & $0.43 \pm 0.01$ & $0.68 \pm 0.13$ & $1.05+0.03$ & $0.25+0.02$ & $0.67 \pm 0.04$ & $1.42 \pm 0.29$ & $2.06 \pm 0.10$ \\
\hline BL-Iron & $2.83 \pm 1.33$ & $4.62 \pm 0.77$ & $3.42 \pm 0.34$ & $2.97 \pm 0.21$ & $1.18 \pm 0.73$ & $1.19+0.10$ & $0.39 \pm 0.08$ & $0.34+0.02$ \\
\hline $\mathrm{pH}_{\text {water }}$ & $5.34 \pm 0.02$ & $5.34 \pm 0.05$ & $5.34 \pm 0.07$ & $5.41 \pm 0.01$ & $5.39 \pm 0.02$ & $5.36 \pm 0.08$ & $5.41 \pm 0.01$ & $5.40 \pm 0.05$ \\
\hline \multicolumn{9}{|c|}{ F. rubra $10 \%$ Moisture Class } \\
\hline BL-Lead & $0.17 \pm 0.01$ & $0.18 \pm 0.01$ & $0.19 \pm 0.00$ & $0.24 \pm 0.04$ & $0.20 \pm 0.00$ & $0.26 \pm 0.04$ & $0.28 \pm 0.07$ & $0.40 \pm 0.14$ \\
\hline BL-Zinc & $1.06 \pm 1.60$ & $0.47 \pm 0.07$ & $0.79 \pm 0.08$ & $1.18 \pm 0.09$ & $0.22 \pm 0.04$ & $0.50 \pm 0.12$ & $0.77 \pm 0.14$ & $1.06 \pm 0.08$ \\
\hline BL-Iron & $0.91 \pm 0.32$ & $2.08 \pm 0.39$ & $1.70 \pm 0.18$ & $1.81 \pm 0.46$ & $1.40 \pm 0.39$ & $3.17 \pm 0.49$ & $3.26 \pm 1.13$ & $2.00 \pm 0.94$ \\
\hline $\mathrm{pH}_{\text {water }}$ & $5.32 \pm 0.03$ & $5.34 \pm 0.04$ & $5.34 \pm 0.01$ & $5.36 \pm 0.01$ & $5.39 \pm 0.02$ & $5.36 \pm 0.03$ & $5.43 \pm 0.02$ & $5.41 \pm 0.02$ \\
\hline \multicolumn{9}{|c|}{ F. rubra $40 \%$ Moisture Class } \\
\hline BL-Lead & $0.20 \pm 0.00$ & $0.20 \pm 0.00$ & $0.19 \pm 0.02$ & $0.19 \pm 0.01$ & $0.21 \pm 0.00$ & $0.21 \pm 0.00$ & $0.21 \pm 0.00$ & $0.21 \pm 0.00$ \\
\hline BL-Zinc & $0.33 \pm 0.02$ & $5.43+4.99$ & $2.21 \pm 0.29$ & $3.03 \pm 0.19$ & $0.31 \pm 0.06$ & $0.87 \pm 0.12$ & $1.48 \pm 0.18$ & $3.41 \pm 0.34$ \\
\hline BL-Iron & $0.58+0.07$ & $0.49 \pm 0.27$ & $0.27 \pm 0.02$ & $0.30 \pm 0.08$ & $0.79 \pm 0.10$ & $0.75+0.04$ & $0.55 \pm 0.05$ & $0.43+0.07$ \\
\hline $\mathrm{pH}_{\text {water }}$ & $5.34+0.02$ & $5.38 \pm 0.09$ & $5.39 \pm 0.02$ & $5.40 \pm 0.03$ & $5.39 \pm 0.01$ & $5.36 \pm 0.07$ & $5.37 \pm 0.02$ & $5.39+0.01$ \\
\hline
\end{tabular}




\section{Appendix B Table}

\begin{tabular}{|c|c|c|c|c|c|c|}
\hline \multicolumn{7}{|c|}{$\begin{array}{l}\text { Metal Concentrations Accumulated in Plant Material over a 49-d Period, in mg kg } \mathrm{mW}^{-1} \mathrm{DW} \text { (mean } \\
\text { values and standard deviations; } \mathrm{N}=4 \text { ) }\end{array}$} \\
\hline \multirow{2}{*}{$\begin{array}{l}\text { Species [Total metal] soil } \\
\left(\mathrm{mg} \mathrm{kg}^{-1} \mathrm{DW}\right)\end{array}$} & \multicolumn{3}{|c|}{ A. pratensis } & \multicolumn{3}{|c|}{ F. rubra } \\
\hline & Shoots & Roots & Plants & Shoots & Roots & Plants \\
\hline \multicolumn{7}{|c|}{ Lead } \\
\hline $50,14 \%$ OM, $10 \%$ Moisture & $8.33+0.00$ & $41.79 \pm 2.33$ & $21.74 \pm 5.79$ & $8.33 \pm 0.00$ & $28.50 \pm 6.11$ & $22.66 \pm 5.13$ \\
\hline $50,14 \%$ OM, $40 \%$ Moisture & $8.33 \pm 0.00$ & $31.96 \pm 3.58$ & $28.83 \pm 2.78$ & $8.33 \pm 0.00$ & $28.08 \pm 5.55$ & $22.67 \pm 7.22$ \\
\hline $50,20 \%$ OM, $10 \%$ Moisture & $8.33 \pm 0.00$ & $31.71 \pm 9.00$ & $24.89 \pm 6.39$ & $8.33 \pm 0.00$ & $22.71 \pm 5.08$ & $17.88 \pm 4.53$ \\
\hline $50,20 \%$ OM, $40 \%$ Moisture & $8.33 \pm 0.00$ & $28.63 \pm 1.44$ & $24.22 \pm 1.59$ & $8.33 \pm 0.00$ & $29.29 \pm 5.01$ & $24.94 \pm 4.19$ \\
\hline $233,14 \%$ OM, $10 \%$ Moisture & $10.42+4.17$ & $123.54 \pm 19.81$ & $96.76 \pm 16.59$ & $8.33 \pm 0.00$ & $125.92+24.41$ & $88.84+20.79$ \\
\hline $233,14 \%$ OM, $40 \%$ Moisture & $8.33 \pm 0.00$ & $228.71+239.82$ & $207.51+211.18$ & $8.33 \pm 0.00$ & $109.17 \pm 23.52$ & $87.72 \pm 16.41$ \\
\hline $233,20 \%$ OM, $10 \%$ Moisture & $8.33 \pm 0.00$ & $69.46 \pm 8.70$ & $53.99 \pm 9.55$ & $8.33 \pm 0.00$ & $70.71 \pm 21.94$ & $41.44 \pm 12.91$ \\
\hline $233,20 \%$ OM, $40 \%$ Moisture & $8.33 \pm 0.00$ & $215.04 \pm 280.01$ & $153.31 \pm 196.23$ & $9.58 \pm 2.50$ & $82.17 \pm 23.34$ & $65.73 \pm 19.75$ \\
\hline $256,14 \%$ OM, $10 \%$ Moisture & $8.33 \pm 0.00$ & $183.63 \pm 52.06$ & $182.42 \pm 81.74$ & $8.33 \pm 0.00$ & $126.29 \pm 38.53$ & $96.06 \pm 40.39$ \\
\hline $256,14 \%$ OM, $40 \%$ Moisture & $10.00 \pm 3.33$ & $356.50 \pm 374.45$ & $333.71 \pm 351.32$ & $8.33 \pm 0.00$ & $124.96 \pm 39.82$ & $99.26 \pm 46.04$ \\
\hline $256,20 \%$ OM, $10 \%$ Moisture & $8.33 \pm 0.00$ & $110.42 \pm 13.76$ & $78.31 \pm 14.56$ & $8.33 \pm 0.00$ & $116.71 \pm 40.50$ & $62.52 \pm 40.50$ \\
\hline $256,20 \%$ OM, $40 \%$ Moisture & $8.33 \pm 0.00$ & $114.79 \pm 10.34$ & $85.82 \pm 10.96$ & $8.33 \pm 0.00$ & $143.00 \pm 56.07$ & $94.99 \pm 47.87$ \\
\hline $331,14 \%$ OM, $10 \%$ Moisture & $12.50 \pm 6.31$ & $389.17 \pm 223.02$ & $353.53 \pm 179.64$ & $8.33 \pm 0.00$ & $384.17 \pm 353.72$ & $270.74+245.31$ \\
\hline $331,14 \%$ OM, $40 \%$ Moisture & $13.33 \pm 4.08$ & $304.17 \pm 68.70$ & $281.49 \pm 63.76$ & $8.75 \pm 0.83$ & $207.21 \pm 52.75$ & $151.25 \pm 58.71$ \\
\hline $331,20 \%$ OM, $10 \%$ Moisture & $12.08 \pm 5.51$ & $217.50 \pm 47.58$ & $158.11 \pm 40.01$ & $8.33 \pm 0.00$ & $218.33 \pm 65.81$ & $142.01 \pm 44.24$ \\
\hline $331,20 \%$ OM, $40 \%$ Moisture & $8.33 \pm 0.00$ & $242.92 \pm 39.24$ & $170.93 \pm 38.35$ & $10.00 \pm 1.92$ & $182.33 \pm 99.20$ & $47.86 \pm 19.27$ \\
\hline \multicolumn{7}{|c|}{ Zinc } \\
\hline $64,14 \%$ OM, $10 \%$ Moisture & $50.00 \pm 5.61$ & $107.17 \pm 12.90$ & $75.34 \pm 12.43$ & $30.83 \pm 2.15$ & $74.96 \pm 3.88$ & $61.82 \pm 1.29$ \\
\hline $64,14 \%$ OM, $40 \%$ Moisture & $42.92 \pm 6.44$ & $135.46 \pm 16.33$ & $123.24 \pm 12.53$ & $33.75 \pm 6.58$ & $96.08 \pm 9.95$ & $77.59 \pm 8.20$ \\
\hline $64,20 \%$ OM, $10 \%$ Moisture & $41.25 \pm 3.44$ & $112.50 \pm 26.54$ & $91.34 \pm 17.38$ & $41.67 \pm 8.28$ & $105.96 \pm 21.76$ & $84.28 \pm 19.86$ \\
\hline $64,20 \%$ OM, $40 \%$ Moisture & $43.33 \pm 3.60$ & $137.25 \pm 27.84$ & $116.14 \pm 18.38$ & $48.33 \pm 19.39$ & $73.83 \pm 9.14$ & $68.46 \pm 8.65$ \\
\hline $163,14 \%$ OM, $10 \%$ Moisture & $84.17 \pm 8.66$ & $193.75 \pm 15.72$ & $167.55 \pm 8.65$ & $50.83 \pm 6.87$ & $210.42 \pm 19.69$ & $159.38 \pm 13.36$ \\
\hline $163,14 \%$ OM, $40 \%$ Moisture & $97.50 \pm 16.47$ & $272.50 \pm 84.56$ & $256.58 \pm 74.94$ & $55.00 \pm 3.04$ & $216.67 \pm 10.14$ & $182.59 \pm 4.14$ \\
\hline $163,20 \%$ OM, $10 \%$ Moisture & $73.75 \pm 11.89$ & $267.08 \pm 26.58$ & $217.19 \pm 19.15$ & $50.42 \pm 8.65$ & $219.17 \pm 29.86$ & $139.83 \pm 22.87$ \\
\hline $163,20 \%$ OM, $40 \%$ Moisture & $94.58 \pm 10.92$ & $418.75 \pm 91.56$ & $320.12 \pm 63.13$ & $50.42 \pm 7.74$ & $247.50 \pm 97.38$ & $202.26 \pm 78.30$ \\
\hline $245,14 \%$ OM, $10 \%$ Moisture & $133.75 \pm 16.07$ & $295.00 \pm 37.44$ & $299.42 \pm 70.26$ & $67.08 \pm 2.50$ & $333.33 \pm 41.37$ & $259.96 \pm 46.97$ \\
\hline $245,14 \%$ OM, $40 \%$ Moisture & $135.83 \pm 18.78$ & $431.25 \pm 143.39$ & $411.43 \pm 136.22$ & $61.25 \pm 11.09$ & $312.08 \pm 42.30$ & $250.27 \pm 66.36$ \\
\hline $245,20 \%$ OM, $10 \%$ Moisture & $133.75 \pm 21.92$ & $518.33 \pm 62.48$ & $394.00 \pm 22.62$ & $64.58 \pm 4.79$ & $352.92 \pm 22.91$ & $196.90 \pm 83.90$ \\
\hline $245,20 \%$ OM, $40 \%$ Moisture & $127.50 \pm 10.41$ & $650.00 \pm 96.18$ & $505.75 \pm 65.27$ & $74.58 \pm 11.50$ & $379.58 \pm 18.43$ & $253.55 \pm 62.05$ \\
\hline & & & & & & (Continued) \\
\hline
\end{tabular}




\begin{tabular}{||l|l|l|l|l|l|l||}
\hline $366,14 \%$ OM, $10 \%$ Moisture & $297.92 \pm 30.86$ & $497.08 \pm 79.25$ & $493.92 \pm 36.22$ & $120.00 \pm 13.40$ & $579.17 \pm 84.52$ & $441.62 \pm 56.39$ \\
\hline $366,14 \%$ OM, $40 \%$ Moisture & $313.33 \pm 31.53$ & $717.92 \pm 106.29$ & $685.95 \pm 96.34$ & $107.92 \pm 27.06$ & $514.58 \pm 56.48$ & $391.40 \pm 73.89$ \\
\hline $366,20 \%$ OM, $10 \%$ Moisture & $211.67 \pm 36.69$ & $761.67 \pm 32.00$ & $601.42 \pm 32.87$ & $89.17 \pm 6.74$ & $572.08 \pm 78.71$ & $397.42 \pm 62.25$ \\
\hline $366,20 \%$ OM, $40 \%$ Moisture & $216.25 \pm 14.62$ & $1001.83 \pm 133.99$ & $779.36 \pm 189.57$ & $127.92 \pm 12.72$ & $598.75 \pm 46.34$ & $233.86 \pm 28.22$ \\
\hline \hline Abbreviation: OM, Organic Matter \\
\hline
\end{tabular}




\section{Appendix C Glossary}

$\begin{array}{ll}\text { Al } & \text { Aluminium } \\ \text { ANOVA } & \text { Analysis Of Variance } \\ \text { BAF } & \text { Biota to Soil Accumulation Factor } \\ \text { BL } & \text { Batch Leach } \\ \mathrm{cm} & \text { centimeter } \\ \mathrm{CO}_{3} & \text { carbonate } \\ \mathrm{Cr} & \text { Chromium } \\ \mathrm{CSCL} & \text { Chemical Stressor Concentration Level } \\ \mathrm{D} & \text { day } \\ \mathrm{DW} & \text { dry weight } \\ \mathrm{EC} & \text { Effective Concentration } \\ \mathrm{Fe} & \text { Iron } \\ \mathrm{g} & \text { gram } \\ \mathrm{h} & \text { hour } \\ \mathrm{ha} & \text { hectare } \\ \mathrm{HCl} & \text { hydrochloric acid } \\ \mathrm{Hg} & \text { Mercury } \\ \mathrm{ICP}-\mathrm{ES} & \text { Inductively Coupled Plasma Analysis Emission Spectrometry } \\ \mathrm{K} & \text { Potassium } \\ \mathrm{KCl} & \text { potassium chloride } \\ \mathrm{kg} & \text { kilogram } \\ \mathrm{L} & \text { liter } \\ \mathrm{LBP} & \text { Lead-Based Paint } \\ \text { LC } & \text { Lethal Concentration } \\ \mathrm{m} & \text { meter } \\ & \end{array}$




$\begin{array}{ll}\mathrm{M} & \text { molar } \\ \mathrm{mg} & \text { milligram } \\ \mathrm{mL} & \text { milliliter } \\ \mathrm{N} & \text { Nitrogen } \\ \mathrm{Ni} & \text { Nickel } \\ \mathrm{OH} & \text { hydroxide } \\ \mathrm{OM} & \text { organic matter } \\ \mathrm{P} & \text { Phosphorus } \\ \mathrm{Pb} & \text { Lead } \\ \mathrm{PAH} & \text { Polyaromatic Hydro Carbon } \\ \mathrm{PCB} & \text { Poly Chlorinated Biphenyl } \\ \mathrm{PT} & \text { Phytotoxicity Threshold } \\ \mathrm{RO} & \text { reverse osmosis } \\ \mathrm{s} & \text { soil } \\ \mathrm{TCLP} & \text { Toxicity Characteristic Leaching Procedure } \\ \text { Ti } & \text { Titanium } \\ \text { XRF } & \text { X-Ray Fluorescence } \\ \text { Zn } & \text { Zinc }\end{array}$




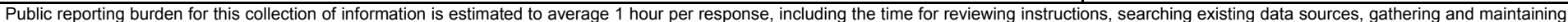

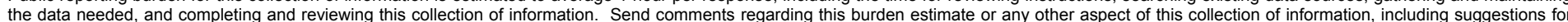

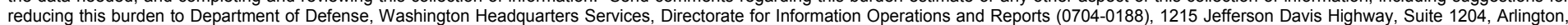

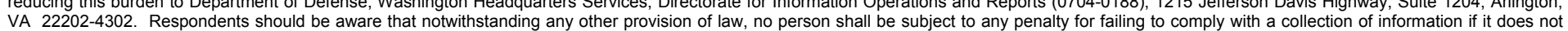
VA 22202-4302. Respondents should be aware that notwithstanding any other provision of law, no person shall be sube
display a currently valid OMB control number. PLEASE DO NOT RETURN YOUR FORM TO THE ABOVE ADDRESS.

\begin{tabular}{l|c}
$\begin{array}{l}\text { 1. REPORT DATE (DD-MM-YYYY) } \\
\text { September } 2004\end{array}$ & $\begin{array}{c}\text { 2. REPORT TYPE } \\
\text { Final report }\end{array}$ \\
\hline
\end{tabular}

\section{TITLE AND SUBTITLE}

Exploration of the Potential for Phytoremediation of Lead-Based-Paint-Contaminated Soil at Fort Lewis, WA

\section{DATES COVERED (From - To)}

5a. CONTRACT NUMBER

5b. GRANT NUMBER

\section{AUTHOR(S)}

Elly P. H. Best, Kaaren N. Geter, and Steven L. Larson

\section{5c. PROGRAM ELEMENT NUMBER}

\section{5d. PROJECT NUMBER}

5e. TASK NUMBER

5f. WORK UNIT NUMBER

8. PERFORMING ORGANIZATION REPORT NUMBER

ERDC/EL TR-04-19

Environmental Laboratory, U.S. Army Engineer Research and Development Center, 3909

Halls Ferry Road, Vicksburg, MS 39180-6199

9. SPONSORING / MONITORING AGENCY NAME(S) AND ADDRESS(ES)

10. SPONSOR/MONITOR'S ACRONYM(S)

U.S. Army Corps of Engineers

Washington, DC 20314-1000

11. SPONSOR/MONITOR'S REPORT NUMBER(S)

\section{DISTRIBUTION / AVAILABILITY STATEMENT}

Approved for public release; distribution is unlimited

\section{SUPPLEMENTARY NOTES}

\section{ABSTRACT}

The current study was conducted to explore the potential for two phytoremediation strategies to remediate lead-based-paint- (LBP) contaminated soil from Fort Lewis, WA, i.e., phytoextraction and phytostabilization. The specific objectives were to (1) determine the potential for phytoextraction and phytostabilization of metals from Pb-contaminated soil from Fort Lewis in herbaceous plants, (2) evaluate the effects of the vegetation on the leachability of the soil, and (3) evaluate the influence of differences in soil characteristics on the vegetation responses.

The tests were performed using Alopecurus pratensis (meadow foxtail) and Festuca rubra (red fescue), i.e., two metal-tolerant turf grass species, with current geographical distributions that include the State of Washington. The plants were incubated with field soil mixtures in a greenhouse on the U.S. ERDC-EL grounds in Vicksburg, MS.

Test results indicated that $A$. pratensis produced on average about twice as much plant biomass as $F$. rubra in 49 days, i.e., 546 versus $249 \mathrm{~g} \mathrm{DW} \mathrm{m}^{-2}$. Both species allocated most of their biomass below ground, and showed the tendency to accumulate Pb solely below ground without upward transport, and to accumulate $\mathrm{Zn}$ largely below ground with limited upward transport. The latter characteristic is typical for plant species used in phytostabilization strategies. A. pratensis was the better metal accumulator, which allocated a relatively higher proportion of its biomass in roots, but was also more sensitive to $\mathrm{Zn}$ than $F$. rubra.

(Continued)

\begin{tabular}{|c|c|c|c|c|c|}
\hline \multicolumn{2}{|l|}{ 15. SUBJECT TERMS } & Grasses & \multicolumn{3}{|c|}{ Phytoremediation } \\
\hline \multicolumn{2}{|l|}{ Alopecurus pratensis } & Lead & \multicolumn{3}{|c|}{ Soil } \\
\hline \multicolumn{2}{|c|}{ Festuca rubra } & Metals & \multicolumn{3}{|c|}{ Zinc } \\
\hline \multicolumn{3}{|c|}{ 16. SECURITY CLASSIFICATION OF: } & $\begin{array}{l}\text { 17. LIMITATION } \\
\text { OF ABSTRACT }\end{array}$ & $\begin{array}{l}\text { 18. NUMBER } \\
\text { OF PAGES }\end{array}$ & $\begin{array}{l}\text { 19a. NAME OF RESPONSIBLE } \\
\text { PERSON }\end{array}$ \\
\hline $\begin{array}{l}\text { a. REPORT } \\
\text { UNCLASSIFIED }\end{array}$ & $\begin{array}{l}\text { b. ABSTRACT } \\
\text { UNCLASSIFIED }\end{array}$ & $\begin{array}{l}\text { c. THIS PAGE } \\
\text { UNCLASSIFIED }\end{array}$ & & 62 & $\begin{array}{l}\text { 19b. TELEPHONE NUMBER (include } \\
\text { area code) }\end{array}$ \\
\hline
\end{tabular}




\section{ABSTRACT (concluded)}

Presence of the vegetation increased the leachability of the soil considerably, but the leachable metal fractions were extremely low (0-0.3 percent) compared to the total soil metal levels. The metals contained in the plant mass represented maximally 2.2 percent of the total metals presumed to be present on site, with only a very small fraction contained in the above-ground, easily harvestable, biomass. Soil-Pb was less bioavailable and accumulated to a lesser extent in the plant material than $\mathrm{Zn}$, probably because $\mathrm{Pb}$ was largely in the form of paint crystals. Increasing soil-Pb levels, concomitant with soil-Zn levels, significantly reduced the shoot and root biomass, increased the tissue- $\mathrm{Zn}$ concentrations in the shoots, and increased the tissue- $\mathrm{Pb}$ and $-\mathrm{Zn}$ concentrations in the roots. Increasing soil organic matter and moisture contents generally stimulated the production of shoot and root biomass.

It was concluded that phytostabilization appears to be a strategy that would considerably reduce ecological risk posed by LBP-contaminated soils at Fort Lewis. The vegetation would concentrate most of the mobile Pb-fraction of the LBP in its root zone, and prevent metals from off-site release as parts of dust particles or dissolved within surface runoff. A. pratensis would be the most suitable species for use on soil contaminated by $\mathrm{Pb}$ alone, and F. rubra on soil contaminated by both $\mathrm{Pb}$ and $\mathrm{Zn}$. Regular mowing and mulching would be a viable management option, which would not spread $\mathrm{Pb}$ around and leave the vegetation intact. Potentially even lower bioavailability and solubility of the LBP-related $\mathrm{Pb}$ in the soil may be attained by removal of the upper $7.5 \mathrm{~cm}$ of the soil or amendment with phosphate rocks. 